\title{
Do toxic algal blooms affect subtidal soft-bottom communities?
}

\author{
Frode Olsgard
}

Section of Marine Zoology and Marine Chemistry, Department of Biology, University of Oslo, PO Box 1064, N-0316 Oslo, Norway

\begin{abstract}
An extensive bloom of the toxic flagellate Chrysochromulina polylepis occurred over much of the Skagerrak and Kattegat area during May-June 1988 with severe effects on biota in shallow marine habitats. Results reported here are from annual grab-sampling of subtidal soft-bottom communities off the southwest coast of Norway during the period 1986 to 1991 at depths between 69 and $184 \mathrm{~m}$, and describe changes in fauna associated with the toxic algal bloom. In the 3 years prior to the bloom the fauna at each station was persistent and only modest year-to-year changes in the number of species, abundance and species composition were observed. Samples collected 1 yr after the bloom event revealed a significant reduction in both number of species and individuals. The most obvious changes were found at sites situated in accumulation areas characterised by fine sediments indicating a possible connection between the quantity of sinking toxic material and the degree of faunal perturbation. A DCA ordination demonstrated a clear switch in faunal composition in the study area subsequent to the bloom, and a tendency of the fauna to return to the pre-bloom communities 2 yr after the bloom event. Principal species affected were moderately abundant oligochaetes, polychaetes, crustaceans, molluscs and sipunculids. Allocation of each species into the categories 'gaining' and 'losing' according to annual changes in abundance gave a good description of the community disturbance probably induced by the toxic alga. Other possible causes for the observed faunal perturbation may be changes in water temperature, food input, predation interference and changes in sediment composition, but none of these were found to give reliable, alternative explanations for the substantial changes observed in the soft-bottom communities subsequent to the toxic bloom.
\end{abstract}

KEY WORDS: Chrysochromulina polylepis - Macrobenthos $\cdot$ Norway $\cdot$ Subtidal $\cdot$ Toxic algae

\section{INTRODUCTION}

A massive bloom of the toxin-producing Prymnesiophycean flagellate Chrysochromulina polylepis Manton et Parke occurred in the Skagerrak and Kattegat in May-June 1988 (Dahl et al. 1989, Dundas et al. 1989, Lindahl \& Dahl 1990). The bloom finally covered an area of about $75000 \mathrm{~km}^{2}$ and was possibly the most spectacular toxic algal bloom hitherto recorded (Granéli et al. 1993). The distribution and maximum concentrations of cells found in the surface waters $(0$ to $20 \mathrm{~m})$ is shown in Fig. 1. Observed maximum concentrations in the pycnocline were 80 to $100 \times 10^{6}$ cells $1^{-1}$ (Underdal et al. 1989, Nielsen et al. 1990), but lethal concentrations in shallow water occurred at a lower threshold of 5 to
$10 \times 10^{6}$ cells $^{-1}$ (Lindahl \& Rosenberg 1989, Underdal et al. 1989). The bloom was accompanied by extensive mortalities of various organisms at depths between 0 and $30 \mathrm{~m}$ on the Norwegian and Swedish coasts of the Skagerrak and the Kattegat (Berge et al. 1988, Gjøsæter 1988, Lindahl \& Rosenberg 1989). Ecological impact of such an extent following an algal bloom has not been previously reported elsewhere (Pedersen et al. 1992).

On the Norwegian coast the bloom resulted in massive damage to farmed fish, littoral wild fish, invertebrate animals and attached algae on rocky bottoms (Berge et al. 1988). In the water column the pycnocline was devoid of heterotrophic flagellates, ciliates and copepods, which re-invaded above the pycnocline after the bloom (Dahl et al. 1989, Nielsen et al. 1990). Labo- 


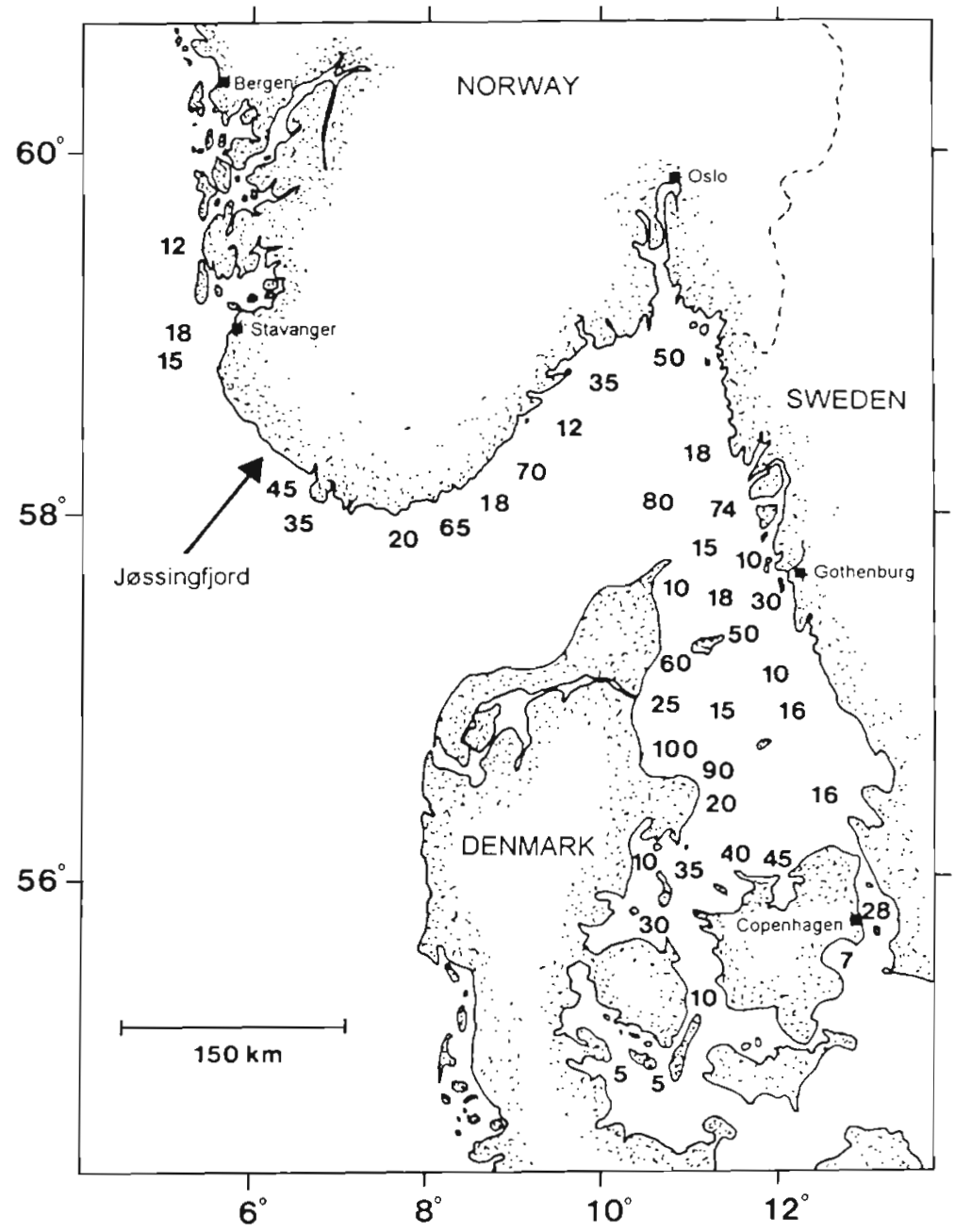

Fig. 1 Distribution and maximum concentrations of Chrysochromulina polylepis $\left(10^{6}\right.$ cells $\left.1^{-1}\right)$ in surface waters $(0$ to $20 \mathrm{~m})$ in the Kattegat and Skagerrak area in May-June 1988. Adapted from Berge et al. (1988). Arrow indicates grab-sampling area rowing sea urchins (Berge et al. 1988) However, after the bloom the number of species and individuals were strongly reduced at some localities (Oug \& Rygg unpubl.). These changes occurred somewhat later than the impact in the littoral (Oug \& Rygg unpubl.).

One problem in the examination of possible impact of the toxic bloom on soft-bottom communities was a lack of long-term data from established monitoring stations. The data presented in this study are from control sites for annual monitoring of a mine tailings disposal site in the Jøssingfjord area in southwestern Norway (Olsgard \& Hasle 1993). High concentrations of Chrysochromulina polylepis (35 to $45 \times 10^{6}$ cells l$^{-1}$; Berge et al. 1988) were observed close to the investigated area.

The effect of a toxic planktonic alga on bottom communities requires transport of the toxic alga and particles containing the toxin to the bottom. If toxic material reaches the sea floor, the greatest proportion is likely to sediment out in accumulating bottoms and not in erosional bottoms. Hence depth and sediment characteristics of each station are important variables in an evaluation of a possible impact of this toxic alga.

Qualitative and quantitative changes were found in the soft-bottom communities in the Jøssingfjord area after the bloom. The aim of this paper is to describe these temporal fluctuations associated with the toxic algal bloom. ratory experiments have shown toxic effects of Chrysochromulina polylepis on eggs and larvae of the ascidian Ciona intestinalis (Granmo et al. 1988), blue mussel Mytilus edulis (Granmo et al. 1988, Nielsen \& Strømgren 1991) and on the nauplii of the crustacean Artemia salina (Edvardsen \& Paasche 1992). The toxin seems to be similar to prymnesin, the toxin produced by Prymnesium, in its haemolytic and cytotoxic characteristics resulting from interaction with cell membranes (Shilo 1981, Underdal et al. 1989, Yasomoto et al. 1990).

During the bloom little damage was reported to softbottom communities (Berge et al. 1988). The few observations on soft-bottom macrofauna for depths down to $75 \mathrm{~m}$ were observations of recently dead polychaetes and molluscs (Pedersen et al. 1989a, E. Oug \& B. Rygg unpubl.) and partial loss of spines from bur-

\section{MATERIALS AND METHODS}

Sampling. Samples were collected annually in March-April at 6 to 10 sites (Fig. 2) from 1986 to 1991 giving 3 yr before and 3 yr after the bloom event. In 1986 and 1991 data are available from 6 stations whereas all 10 stations were sampled each year from 1987 to 1990 . The sampling sites were mainly located along deep channels or in typical sedimentation areas at depths between 69 and $184 \mathrm{~m}$. Triplicate $0.1 \mathrm{~m}^{2}$ van Veen grab samples were taken at each station during the winter or early spring to avoid unstable communities and periods of heavy larval settlement. The grabsamples were sieved on $5 \mathrm{~mm}$ and $1 \mathrm{~mm}$ mesh screens with round holes. The sieve residues were fixed in $4 \%$ buffered formaldehyde, stained with Rose Bengal, sorted and later preserved in $70 \%$ ethanol. Animals 


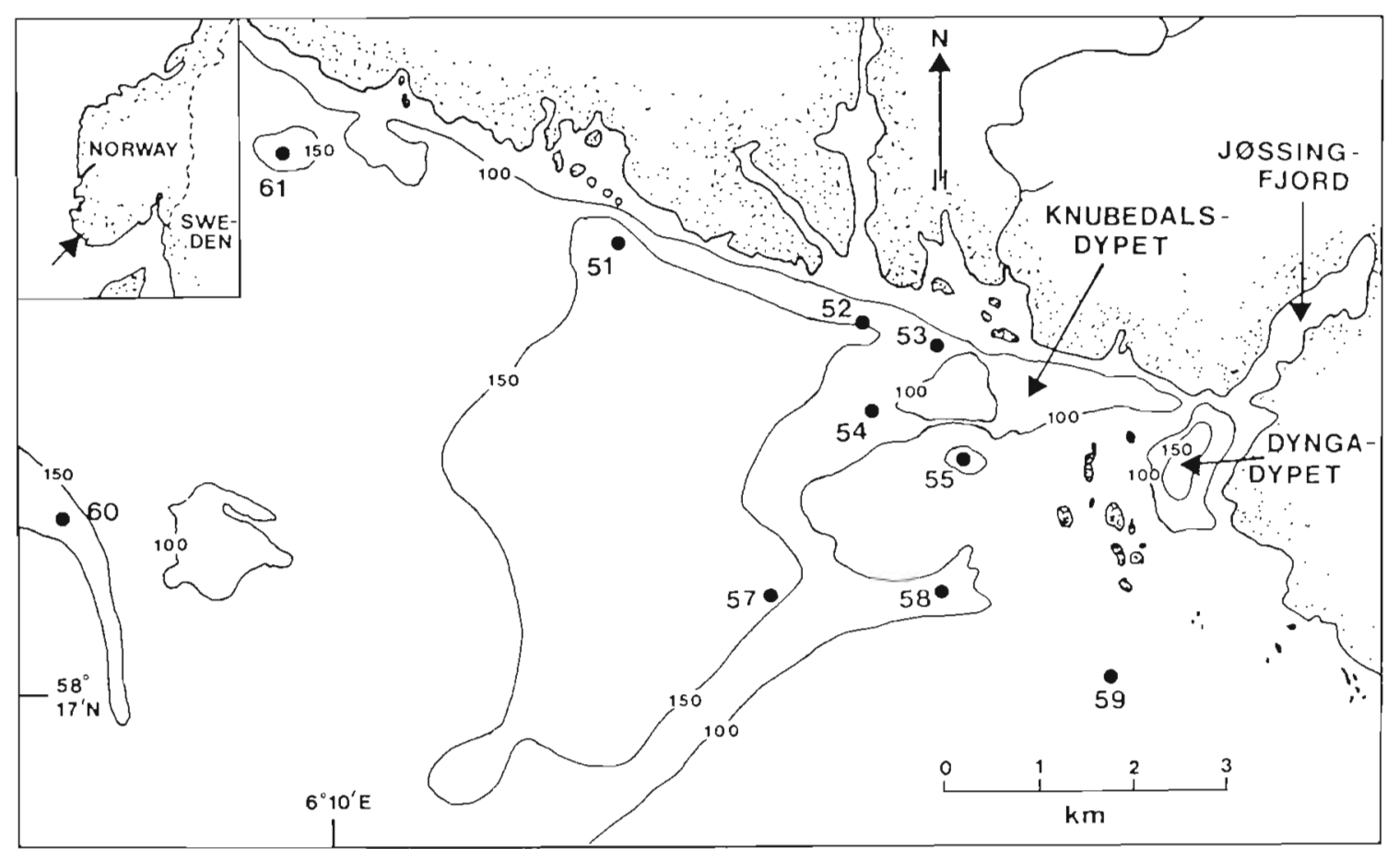

Fig. 2. Location of the 10 sampling sites

were identified to species level or, where this proved difficult, to genus, family or higher taxonomic levels. Sediment samples for analysis of grain size distribution and organic matter were collected with a $63 \mathrm{~mm}$ diameter gravity corer at each station each year, except at the most shallow, sandy station which was sampled using a $0.1 \mathrm{~m}^{2}$ van Veen grab

Sediment analysis. Organic content of the sediments was determined as weight loss on ignition $\left(450^{\circ} \mathrm{C}, 24 \mathrm{~h}\right)$ and grain size distribution by sieving (>0.063 $\mathrm{mm}$ ) and cyclosizer $(<0.063 \mathrm{~mm})$. The particle sizes were classified into phi-units (phi $=-\log _{2}$ of the particle diameter) and the central tendency measured as median phi-size (Krumbein \& Pettijohn 1938).

The sites were grouped according to their environmental characteristics (depth and sediment variables) using Principal Component Analysis (PCA) on $\log _{10}$ (depth) or arcsin (percentage organic matter, silt-clay and fines) transformed values. A $\log _{2}$ transformation is already employed in the calculation of median particle size; therefore no further transformation was required for this parameter.

Faunal analysis. A total of 383 species were identified from 1986 to 1991 . No species reduction was applied to the fauna data matrix prior to multivariate analysis. Fauna samples from Stn 59, the most shallow station with coarse sediments, were so markedly different from others that they were not included in the multivariate analysis. Removal of such 'outliers' is recommended to avoid severe interference in the site groupings of the remaining stations (e.g. Gauch 1982, Jongman et al. 1987).

Relationships between community structure and the environmental variables depth, organic content of sediment, silt-clay (particles $<0.063 \mathrm{~mm}$ ), fine (particles $<0.010 \mathrm{~mm}$ ) and median particle size were determined by correlating the obtained ordination axes in a DCA (Detrended Correspondence Analysis; Hill \& Gauch 1980) fauna ordination with the environmental variables resulting in a biplot, using the programme CANOCO (Ter Braak 1988).

Diversity of each site was measured using the Shannon-Wiener diversity $H^{\prime}$ (Shannon \& Weaver 1963) to a $\log _{2}$ base and Margalef diversity $d$ (Margalef 1958), while evenness was calculated using Pielou's index of evenness (Pielou 1966).

The significance of changes in number of species and abundance at each station during the period 1986 to 1991 was tested with a 1-way ANOVA (Sokal \& Rohlf 1981) with replication $\left(\mathrm{n}=3\right.$ ) on $\log _{10}$ transformed data. Homogeneity of variances were examined with Bartlett's test (Sokal \& Rohlf 1981). Differences of means were examined with a LeastSignificant-Difference (LSD) test (Sokal \& Rohlf 1981).

The significance of decrease of number of species and abundance from 1988 to 1989 and increase from 1989 to 1990 was tested with a binominal test (Siegel 1956).

In order to examine if the observed reduction in number of species and individuals from 1987/88 to 
1989 could be related to characteristics of the bottom sediments, linear regression coefficients were calculated between the reduction in number of species and individuals and the PCA coordinates of Axis 1, which represented most ( $>99 \%$ ) of the sediment information. The potential of a given sediment to receive and accumulate possible toxic algal material from the euphotic zone should largely be expressed in the measured sediment characteristics, and one would expect the fauna in areas with fine bottom sediments to be most exposed to settling toxic material.

The species data matrix was subjected to a double square-root transformation before computation of the Bray-Curtis similarity coefficient (Bray \& Curtis 1957) between sites. This transformation was applied in order to reduce the effect of dominant species on the Bray-Curtis coefficient (Field et al. 1982). The similarity-matrix was then subjected to a hierarchical, agglomerative classification employing group-average linking (Lance \& Williams 1967). The significance of faunistic differences between site groupings was determined using the ANOSIM randomization test (Clarke \& Green 1988). To examine yearly gross changes in fauna within the entire sampling area a summary matrix of all sites for each individual year was extracted from the double square-root species matrix and subjected to DCA ordination.

Between 1988 and 1989 a reduction in number of species and individuals was observed at most stations resulting in a change in faunal similarity within each station. Species having the greatest contribution to this change were determined using the similarity percentages programme SIMPER (Warwick et al. 1990). From the SIMPER analysis the 30 principal species at each station were listed. For most species (> $80 \%$ ) the high ranking in the SIMPER analysis was a result of a reduction in abundance from $1987 / 88$ to 1989 . In other words topranked species in the SIMPER analysis showing a reduction in abundance were the central species for the observed changes in faunal similarity in the survey area from 1988 to 1989 . From the lists of 30 principal species those showing a reduction in abundance at all sites from $1987 / 88$ to 1989 were extracted. Those central species were further classified into functional groups according to feeding categories and reproduction. The feeding categories chosen were deposit-feeders, surface depositfeeders, suspension-feeders, carnivorous and omnivorous. Reproductive categories were planktotrophic species which have larvae with long pelagic lives that depend on food from plankton, and lecithotrophic species which have larvae with short pelagic stages that depend primarily on the yolk. The classification into functional groups was based on Sanders (1960), Hartmann-Schröder (1971), Pearson (1971), Fauchald \& Jumars (1979) and Josefson $(1981,1986,1987)$.
The individual speries populations at each station were divided into (1mups defined by the nature of their annual population changes. These were: 'gaining' species which exhibit d gain from one year to the next, 'losing' species which show loss between individual years and finally 'neutral' species with no change from one year to the next. If the year-to-year variation is random one expects an equal number of gaining and losing species in a community. The null hypothesis would be the proportion of gaining and losing species being equal. If a community is exposed to stress one expects that more species would decrease in abundance than increase, which implies a decrease in gaining and increase in losing species, as a response to the stressor. The significance of changes in percentage of number of species in each group between years for all stations was tested with a 1-way ANOVA on arcsintransformed data. For each group $95 \%$ confidence intervals based on mean square values were calculated. Wilcoxon matched-pairs signed-ranks test (Siegel 1956) was used to test the significance and magnitude of change between years within each station. The resulting $z$-statistics indicate the magnitude and the direction of change. A positive $z$-value indicates an increase in gaining species while a negative $z$-value indicates an increase in losing species.

\section{RESULTS}

The PCA ordination of the sediment data is shown in Fig. 3. Except for Stn 59, the most shallow station, only

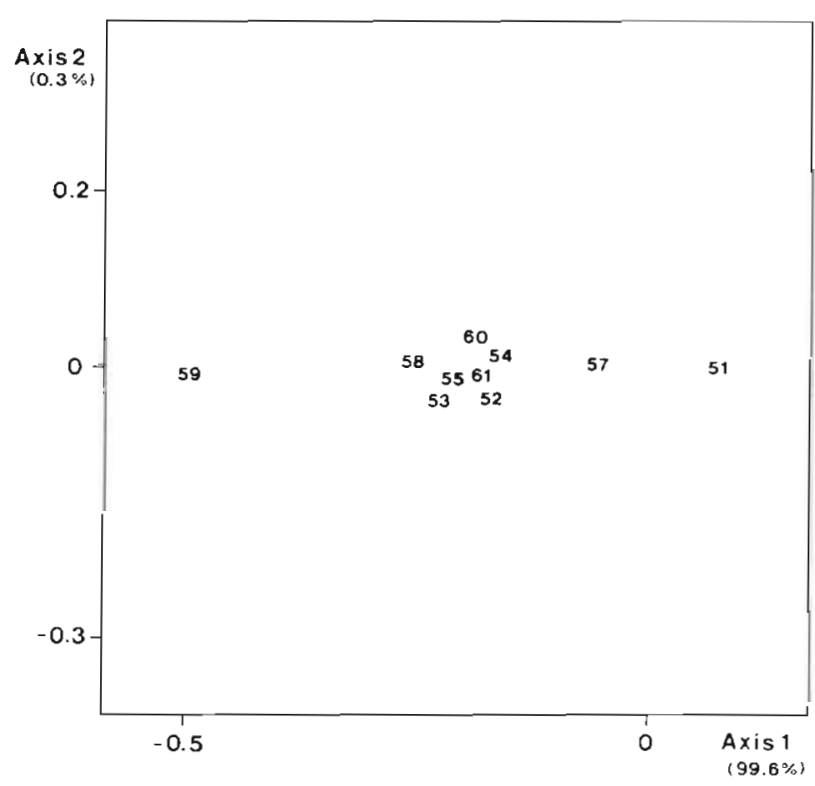

Fig. 3. PCA ordination of the stations according to depth and sediment characteristics 
Table 1. Depth and sediment characteristics at the sampling sites in the period 1986-1991 (Mean \pm SD)

\begin{tabular}{|cccccc|}
\hline Site & $\begin{array}{c}\text { Depth } \\
(\mathrm{m})\end{array}$ & $\begin{array}{c}\text { Organic } \\
\text { matter }(\%)\end{array}$ & $\begin{array}{c}\text { Silt-clay } \\
(\%<63 \mu \mathrm{m})\end{array}$ & $\begin{array}{c}\text { Fines } \\
(\%<10 \mu \mathrm{m})\end{array}$ & $\begin{array}{c}\text { Median particle- } \\
\text { size }(\phi-\text {-scale })\end{array}$ \\
\hline 51 & $171.2 \pm 1.0$ & $5.4 \pm 0.6$ & $75.2 \pm 2.9$ & $59.7 \pm 7.3$ & $7.2 \pm 0.1$ \\
52 & $137.0 \pm 2.4$ & $2.3 \pm 0.3$ & $35.4 \pm 2.7$ & $19.0 \pm 1.3$ & $3.2 \pm 0.1$ \\
53 & $116.8 \pm 0.8$ & $1.9 \pm 0.4$ & $28.3 \pm 3.3$ & $16.0 \pm 3.0$ & $3.0 \pm 0.6$ \\
54 & $123.0 \pm 1.6$ & $2.0 \pm 0.1$ & $29.4 \pm 2.7$ & $17.2 \pm 1.6$ & $3.2 \pm 0.1$ \\
55 & $108.3 \pm 0.5$ & $2.3 \pm 0.4$ & $32.1 \pm 3.0$ & $39.4 \pm 1.7$ & $3.1 \pm 0.1$ \\
57 & $182.3 \pm 2.6$ & $3.6 \pm 0.6$ & $52.7 \pm 1.0$ & $16.0 \pm 2.1$ & $3.8 \pm 0.3$ \\
58 & $170.0 \pm 1.8$ & $2.3 \pm 0.4$ & $20.6 \pm 2.9$ & $2.4 \pm 0.6$ & $2.9 \pm 0.1$ \\
59 & $70.7 \pm 1.6$ & $1.4 \pm 0.6$ & $4.9 \pm 3.9$ & $22.1 \pm 3.2$ & $0.6 \pm 1.3$ \\
60 & $171.5 \pm 1.3$ & $2.2 \pm 0.2$ & $29.3 \pm 3.1$ & $2.9 \pm 0.1$ \\
61 & $162.2 \pm 0.5$ & $2.8 \pm 0.4$ & $33.4 \pm 3.5$ & $3.0 \pm 0.1$ \\
\hline
\end{tabular}

minor year-to-year changes were found in sediment characteristics within each station. The input data in the PCA-ordination was therefore based on mean values (Table 1) for each separate station. Along this first ordination axis $99.6 \%$ of the total variation within the data-set was explained, which indicates that almost all differences in sediment characteristics between stations are explained along this axis. The first axis thus represents a gradient of sediment type. Stn 51 has fine sediments high in organic matter, while Stn 59 has coarse sediments low in organic matter. The remaining stations have characteristics between these 2 stations.

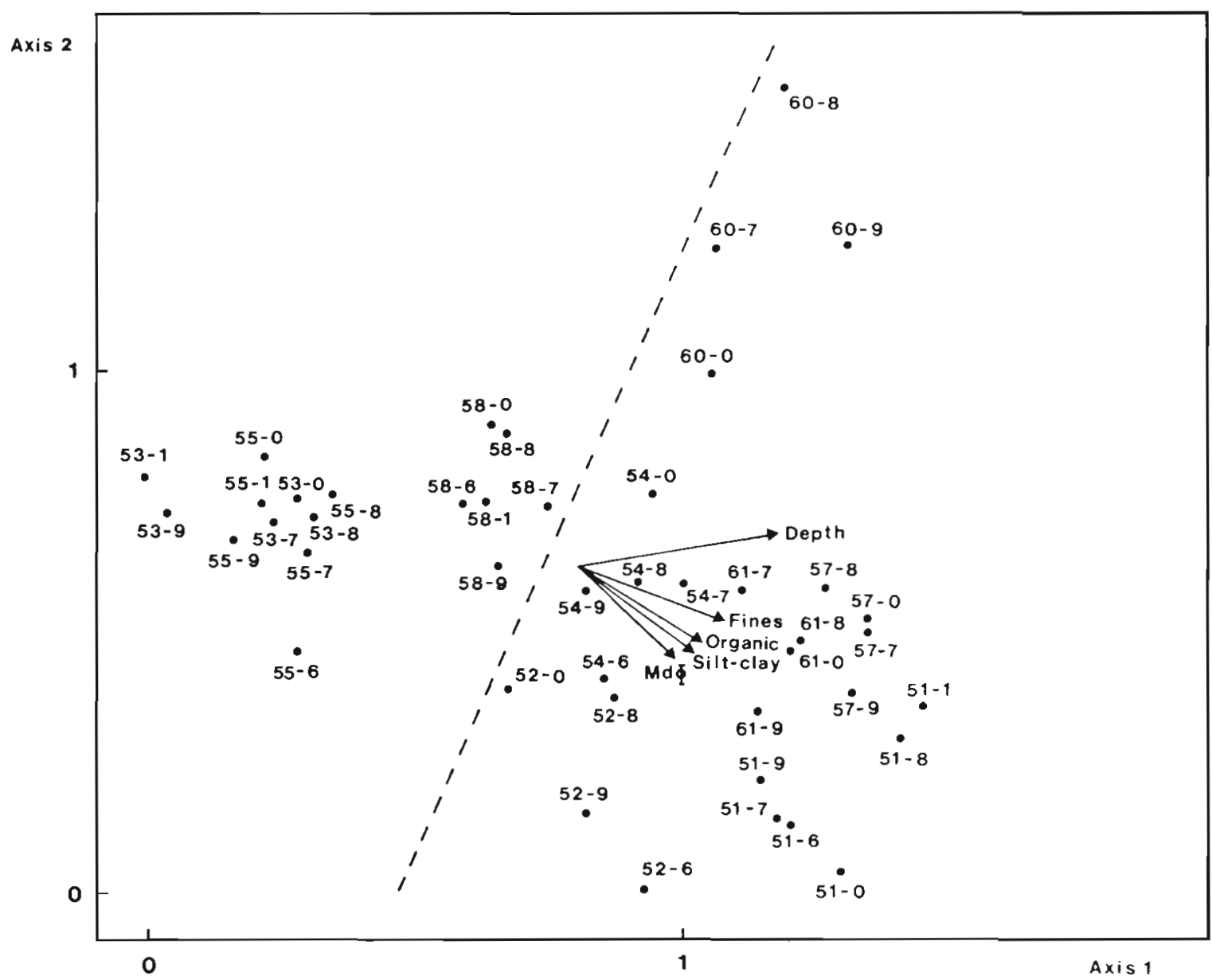

Fig. 4. Biplot of the DCA fauna ordination and the environmental variables. Station numbers are given with an extension indicating year of sampling (e.g. $51-3$ is Stn 51 in 1983) 
Assuming that the observed coarseness-fineness gradient reflects an erosion-sedimentation gradient, the benthic communities in the sedimentation areas a priori therefore are expected to be more exposed to sinking toxic material than communities occupying eroding sediments.

A DCA ordination of the fauna was run separately followed by a correlation between the obtained fauna ordination with the environmental variables resulting in a biplot (Fig. 4). The eigenvalues of Axes 1 and 2 in the ordination were 0.16 and 0.11 , respectively. In the biplot the environmental variables are displayed as arrows pointing in the direction of maximum correlation of each variable, giving a qualitative indication of the correlation between the fauna at each station and the environmental variables. A t-test of pairwise correlation between the ordination axes and the environmental variables showed that both depth, proportion of silt-clay, proportion of fine and median particle size were significantly related $(p<0.05)$ to the 2 ordination axes. The stations to the right of the dashed line (Fig. 4) are more or less correlated with increasing depth, high percentage of organic matter, proportion of silt-clay and fine particles in the sediments as well as high values of median particle size which also indicate fine sediments. The sediments at these stations possess properties characteristic of accumulation bottoms. The stations to the left of the dashed line were negatively correlated with increasing depth and fine sediments, and have properties less characteristic of sedimentation areas. The plot gives clear indications of a connection between the bot tom sediments and the benthic communities in the area.

The change in number of species and individuals in 1989. compared to the preceding years, was obvious at several stations (Fig. 5). At Stns 51, 52 \& 60 there was a

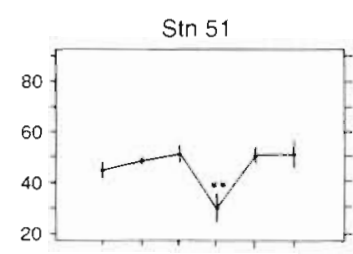

$\operatorname{Stn} 52$

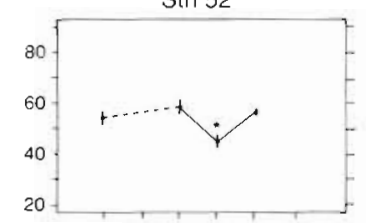

$\operatorname{Stn} 53$

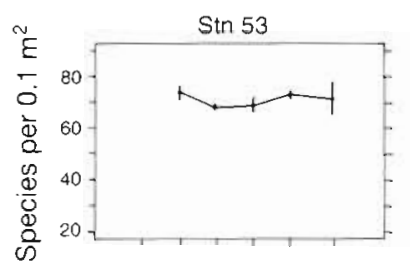

$\operatorname{Stn} 54$

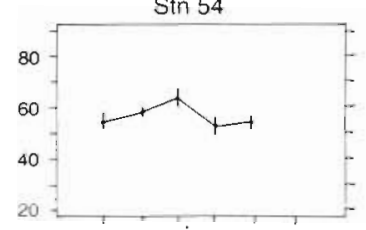

$\operatorname{Stn} 55$

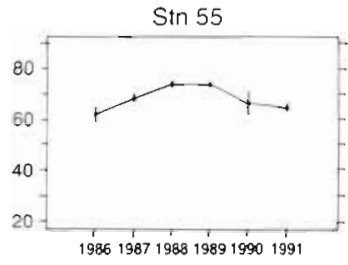

YEARS

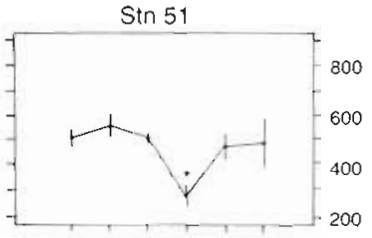

$\operatorname{Stn} 52$
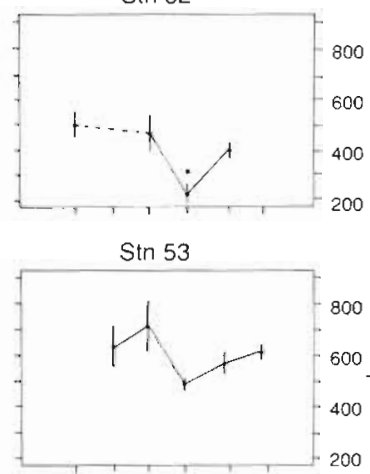

$\sin 54$
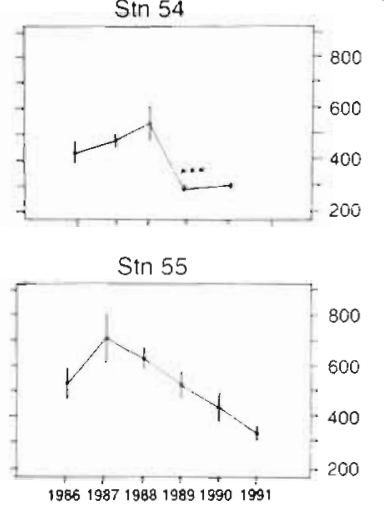

YEARS
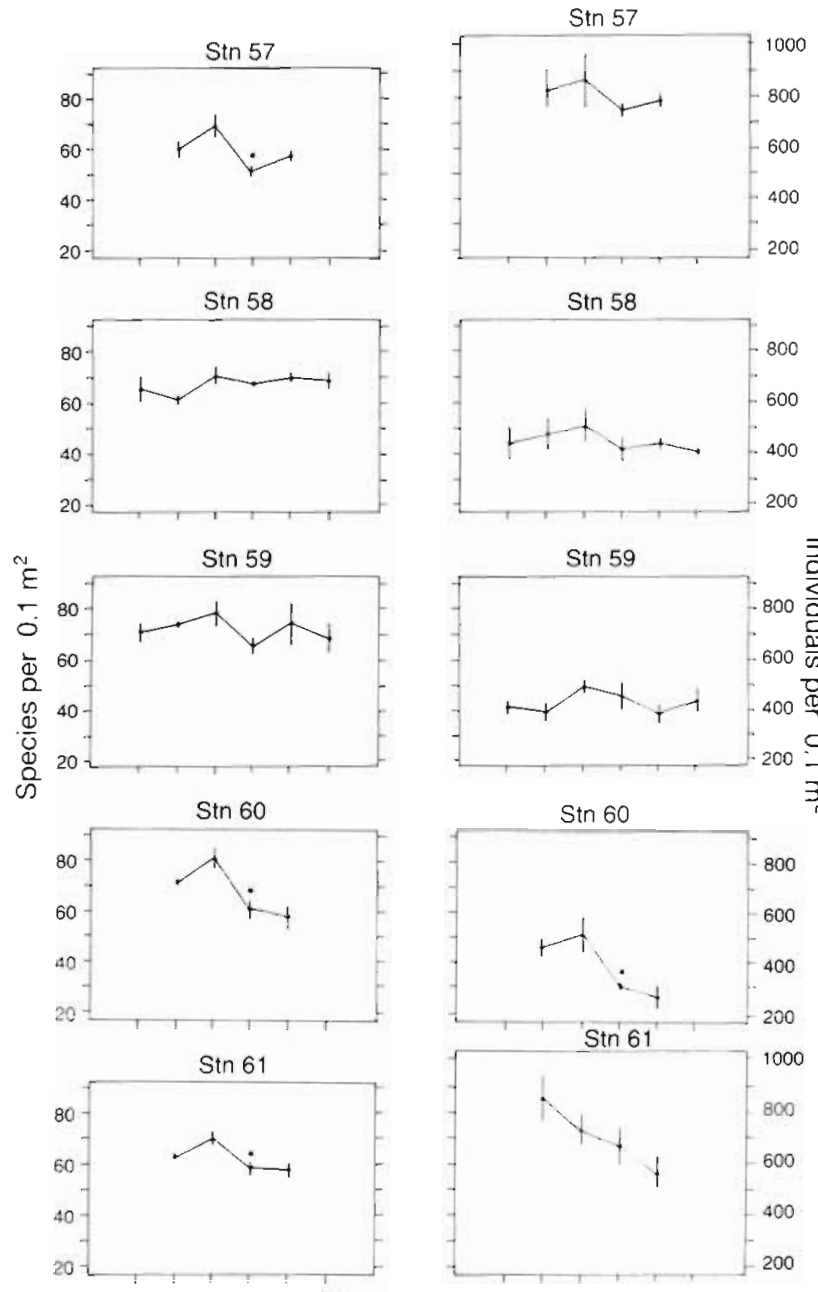

198615871989198919901991

YEARS
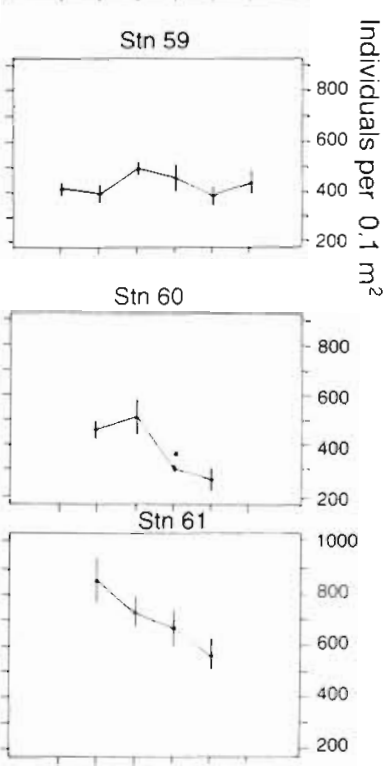

198619871988198919901991

YEARS

Fig. 5. Variations in number of species (left) and individuals (right) per $0.1 \mathrm{~m}^{2}$ ( \pm SEM) at the sampling sites. Signifıcance levels from a 1-way ANOVA comparing number of species or individuals between April 1988 (pre-bloom) and April 1989 (subsequent to the bloom) are indicated by asterisks: $p<0.05 ; " p<0.01 ; \cdots p<0.001$; no asterisk $p>0.05$ (not signuficant) 
Table 2. Mean percentage of change $(\bar{x} \pm$ SEM) in number of species and individuals for all sites $(n=10)$ respectively 1 and 2 yr after the toxic bloom. Proportion of stations with a decrease (d) from 1988 to 1989 and a subsequent increase (i) from 1989 to 1990 and level of significance is also given (binominal-test)

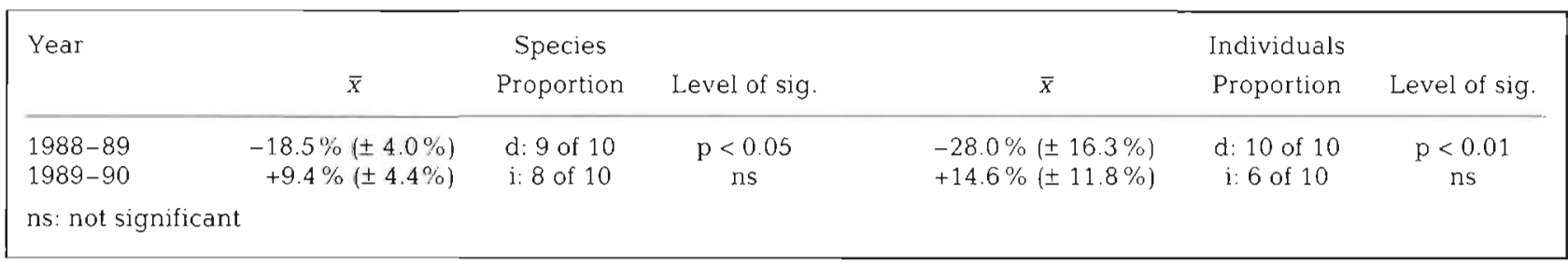

significant reduction in both number of species and abundance in 1989 compared to the 2 preceding years. At $\operatorname{Stn} 54$ there was a significant reduction in abundance while at Stns $57 \& 61$ there was a significant reduction in number of species. At the remaining stations there was a decline in either number of species, abundance or both after the bloom, although these were not significant.

The percentage reduction in number of species and abundance from 1988 to 1989 is given in Table 2. A decrease in the number of species was observed at 9 out of 10 stations ( $p<0.05$ ) with a mean reduction of $18.5 \%$, while the decrease in number of individuals involved all 10 stations $(\mathrm{p}<0.01)$ with a mean reduction of $28.0 \%$. From 1989 to 1990 an increase in both number of species and abundance was observed. The mean increase in number of species and abundance in this period was $9.4 \%$ and $14.6 \%$, respectively (Table 2).

Shannon-Wiener's diversity and Pielou's evenness at each station from 1986 to 1991 are given in Table 3. Only at Stn 51 was there a clear change in diversity and evenness although many stations displayed an apparent reduction in number of species or individuals or both from 1988 to 1989 . For example, at Stn 60 from 1988 to 1989 , the number of species was reduced from 123 to 100 and abundance from 1550 to 940 individuals

Table 3. Margalef's diversity (d), Shannon-Wiener's diversity $\left(H^{\prime}\right)$ and Pielou's evenness $\left(J^{\prime}\right)$ per $0.3 \mathrm{~m}^{2}$ from 1986 to 1991

\begin{tabular}{|c|c|c|c|c|c|c|c|c|c|}
\hline Stn & Year & $d$ & $H^{\prime}$ & $J^{\prime}$ & Stn & Year & $d$ & $H^{\prime}$ & $J^{\prime}$ \\
\hline \multirow[t]{7}{*}{51} & 1986 & 8.1 & 3.51 & 0.59 & \multirow[t]{5}{*}{57} & 1987 & 11.6 & 3.51 & 0.54 \\
\hline & 1987 & 8.7 & 3.89 & 0.64 & & 1988 & 13.1 & 4.06 & 0.61 \\
\hline & 1988 & 9.9 & 4.40 & 0.71 & & 1989 & 9.1 & 3.55 & 0.58 \\
\hline & 1989 & 7.6 & 2.91 & 0.51 & & 1990 & 11.2 & 3.43 & 0.53 \\
\hline & 1990 & 8.9 & 4.40 & 0.73 & & & & & \\
\hline & 1991 & 10.2 & 4.57 & 0.73 & \multirow{6}{*}{58} & 1986 & 14.0 & 5.14 & 0.77 \\
\hline & & & & & & 1987 & 13.5 & 4.86 & 0.73 \\
\hline \multirow[t]{4}{*}{52} & 1986 & 11.3 & 4.46 & 0.70 & & 1988 & 15.0 & 4.57 & 0.67 \\
\hline & 1988 & 12.2 & 4.67 & 0.72 & & 1989 & 14.4 & 4.80 & 0.72 \\
\hline & 1989 & 10.0 & 4.53 & 0.75 & & 1990 & 15.3 & 4.80 & 0.70 \\
\hline & 1990 & 11.6 & 4.69 & 0.73 & & 1991 & 14.4 & $\begin{array}{l}4.00 \\
5.16\end{array}$ & 0.77 \\
\hline \multirow[t]{6}{*}{53} & 1987 & 14.5 & 4.97 & 0.73 & \multirow{6}{*}{59} & & & & \\
\hline & 1988 & 13.4 & 4.81 & 0.72 & & 1986 & 17.2 & 5.32 & 0.78 \\
\hline & 1989 & 14.0 & 4.96 & 0.74 & & 1987 & 16.2 & 5.54 & 0.83 \\
\hline & 1990 & 14.1 & 4.76 & 0.71 & & 1988 & 17.3 & 5.63 & 0.81 \\
\hline & 1991 & 14.9 & 4.90 & 0.72 & & 1989 & 12.9 & 5.18 & 0.81 \\
\hline & & & & & & 1990 & 16.4 & 5.46 & 0.81 \\
\hline \multirow[t]{6}{*}{54} & 1986 & 11.8 & 4.84 & 0.73 & & 1991 & 13.7 & 5.18 & 0.80 \\
\hline & 1987 & 12.5 & 4.40 & 0.68 & & & & & \\
\hline & 1988 & 13.7 & 4.47 & 0.67 & \multirow{5}{*}{60} & & & & \\
\hline & 1989 & 11.7 & 4.77 & 0.76 & & 1987 & 13.6 & 5.19 & 0.78 \\
\hline & 1990 & 12.8 & 4.80 & 0.74 & & 1988 & 16.6 & 5.41 & 0.78 \\
\hline & & & & & & 1989 & 14.5 & 5.41 & 0.81 \\
\hline \multirow{6}{*}{55} & & 11.5 & 4.82 & 0.75 & & 1990 & 13.3 & 5.26 & 0.81 \\
\hline & 1987 & 13.6 & 4.66 & 0.69 & & & & & \\
\hline & 1988 & 15.0 & 4.91 & 0.72 & \multirow[t]{4}{*}{61} & 1987 & 11.8 & 4.63 & 0.71 \\
\hline & 1989 & 15.9 & 4.94 & 0.72 & & 1988 & 14.0 & 4.63 & 0.69 \\
\hline & 1990 & 14.4 & 4.79 & 0.72 & & 1989 & 10.7 & 4.14 & 0.65 \\
\hline & 1991 & 12.8 & 5.11 & 0.79 & & 1990 & 11.2 & 4.44 & 0.70 \\
\hline
\end{tabular}


while the Shannon-Wiener diversity index remained unaltered at $H^{\prime}=5.41$. Furthermore, at Stn 54 diversity even increased from $H^{\prime}=4.47$ to $H^{\prime}=4.77$ when the number of species was reduced from 103 to 80 and abundance from 1667 to 844 individuals. Diversity indices therefore were not suitable for measuring the observed ecosystem perturbation.

The reduction in number of species and abundance from $1987 / 88$ to 1989 were correlated against the coordinates of PCA Axis 1, which represented almost all the sediment variation. No significant correlation $(r=0.026$, $\mathrm{n}=10, \mathrm{p}=0.467$ ) was found between sediment type and reduction in number of species, while the observed reduction in abundance was significantly correlated $(\mathrm{r}=0.697, \mathrm{n}=10, \mathrm{p}=$ 0.025) to these sediment parameters (Fig. 6). This indicates that the most distinct reduction in abundance was found at stations situated in accumulation areas.

Classification of the species matrix for the period 1986 to 1991 resulted in 3 main site groups (Fig. 7). An ANOSIM-test clearly indicated that the obtained site groupings (a, b and c) were significantly different $(p<0.05)$. Site group a consisted of Stns 51, 52, 54, $57 \&$ 61 , site group b of Stns $53,55 \& 58$ while site group c consisted of the single Stn 60 . The resulting dendrogram shows that each station was more or less grouped

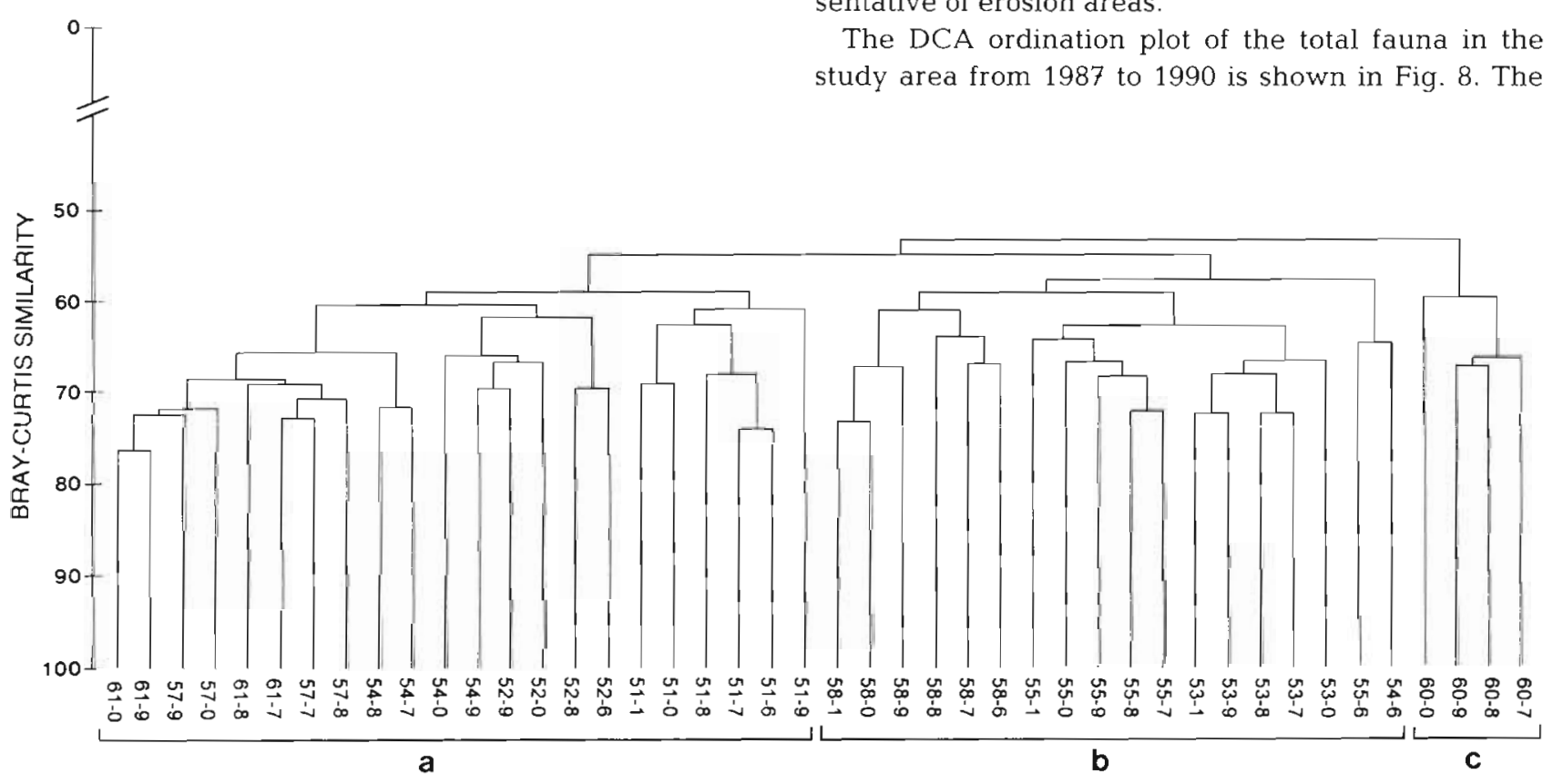

Fig. 7. Classification of the stations from 1986 to 1991. Station numbers are given with an extension indicating year of sampling (e.g. 51-3 is Stn 51 in 1983) together during the 6 yr of monitoring, whereas clearer changes were found within the different stations. The most apparent within-station changes took place in site group a from 1988 to 1989 . In this site group all stations showed a switch within the dendrogram between these 2 years. The stations in site group a represent sedimentation areas. Less changes were observed at stations within fauna site group b (Stns 53, 55, 58 \& 59) which all have less fine sediments and are more representative of erosion areas.

The DCA ordination plot of the total fauna in the study area from 1987 to 1990 is shown in Fig. 8. The 
resulting eigenvalues of Axes 1 and 2 in the DCA ordination were 0.42 and 0.25 , respectively. In the study area a change in faunal composition has clearly taken place after the Chrysochromulina polylepis bloom in 1988. The ordination plot illustrates a maximum faunal dissimilarity in 1989 compared to the years prior to the bloom (1987 and 1988), and that the fauna in 1990 has a tendency to become more similar to the pre-bloom communities.

The 30 principal species in the SIMPER-analysis were listed for each separate station. Table 4 is an extract of these results and lists those species, among the 30 principal ones, which were recorded in reduced abundance from $1987 / 88$ to 1989 at all 10 stations. Species from all the main phyla, except Echinodermata, are represented. Reduced abundance is found for species within all trophic levels, with lecithotrophic or planktotrophic larvae, with dissimilar breeding periods and with different life-spans. The species in Table 4 account for 23.5 to $85.2 \%$ (mean value $52.8 \%$ ) of the total reduction in abundance recorded between $1987 / 88$ and 1989

Table 5 lists species disappearing completely from at least $30 \%$ of the stations from 1988-89. For compari-

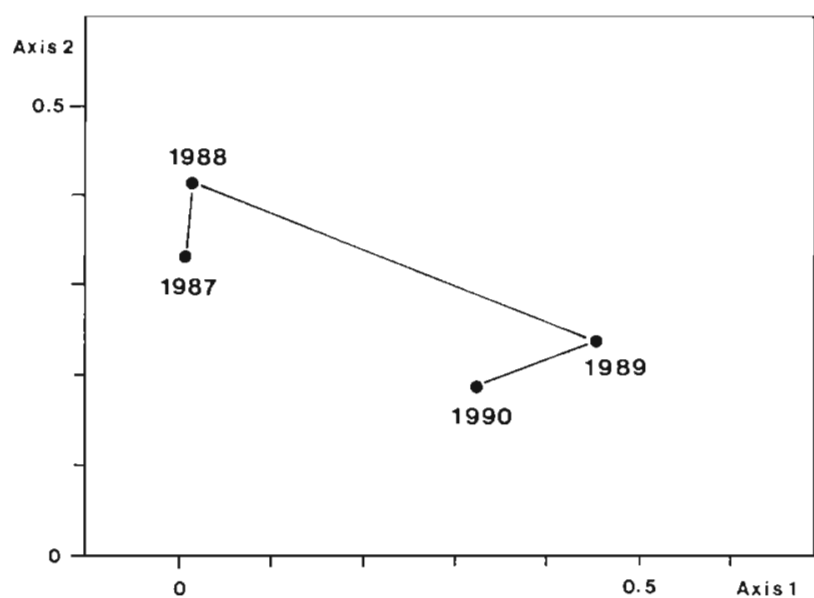

Fig. 8. DCA ordination of total fauna in the study area from 1987 to 1990

son, similar data for $1987-88$ and for $1989-90$ are also given. Clearly a higher number of species disappeared after the bloom compared to the year before and $2 \mathrm{yr}$ after. The number of species disappearing 2 yr after the bloom event was also higher than the pre-bloom

Table 4. Principal species from the SIMPER analysis with reduced abundance at all 10 stations from 1987/88 to 1989. Mean abundance $\left(\bar{x}\right.$ per $\left.0.3 \mathrm{~m}^{2}\right)$ and mean \% reduction from $1987 / 88$ to 1989 and trophic level $(C=$ carnivore, SDF $=$ surface deposit-feeder, $\mathrm{DF}=$ deposit-feeder, $\mathrm{SF}=$ suspension-feeder), type of larva (Le = lecithotrophic development, $\mathrm{Pl}=$ planktotrophic development $)$, breeding period and life-span are indicated

\begin{tabular}{|c|c|c|c|c|c|c|c|}
\hline Fauna element & $\begin{array}{c}\bar{x} \text { per } 0.3 \mathrm{~m}^{2} \\
1987 / 88\end{array}$ & $\begin{array}{c}\bar{x} \text { per } 0.3 \mathrm{~m}^{2} \\
1989\end{array}$ & $\begin{array}{l}\text { Reduction } \\
(\%)\end{array}$ & $\begin{array}{c}\text { Trophic } \\
\text { level }\end{array}$ & Larva & $\begin{array}{l}\text { Breeding } \\
\text { period }\end{array}$ & $\begin{array}{l}\text { Life span } \\
\quad(y \Gamma)\end{array}$ \\
\hline \multicolumn{8}{|l|}{ Oligochaeta } \\
\hline Oligochaeta spp. & 89.1 & 58.3 & 34.5 & DF & Le & - & - \\
\hline \multicolumn{8}{|l|}{ Polychaeta } \\
\hline Glycera capitata & 18.5 & 10.6 & 42.7 & C/SDF & $\mathrm{Pl}$ & - & $>5$ \\
\hline Augeneria tentaculata & 10.8 & 7.2 & 33.3 & C & Le & - & - \\
\hline Prionospio cirrifera & 25.6 & 19.1 & 25.5 & SDF & $\mathrm{Pl}$ & Jul-Aug & $<2$ \\
\hline Diplocirrus glaucus & 5.7 & 3.7 & 35.0 & $\mathrm{DF}$ & Le & May-Aug & $>1$ \\
\hline Paramphinome jeffreysii & 41.2 & 26.1 & 36.7 & $\mathrm{C}$ & Pl & $\mathrm{Jan}-\mathrm{Feb}$ & 2 \\
\hline Melinna cristata & 51.4 & 25.3 & 50.8 & SDF & Le & Dec-Jan & - \\
\hline Proclea graffi & 33.4 & 6.8 & 79.6 & SDF & Le & - & - \\
\hline Terebellides stroemi & 3.9 & 0.6 & 84.8 & SDF & Le & May-Oct & - \\
\hline Chone duneri & 7.5 & 4.5 & 40.0 & $\mathrm{SF}$ & - & - & - \\
\hline Sabellidae spp. & 51.8 & 23.4 & 54.8 & SF & - & - & - \\
\hline \multicolumn{8}{|l|}{ Crustacea } \\
\hline Tanaidacea spp. & 22.4 & 5.3 & 76.3 & SDF & - & - & - \\
\hline Eudorella emarginata & 4.5 & 1.8 & 59.5 & SDF & Le & - & - \\
\hline \multicolumn{8}{|l|}{ Mollusca } \\
\hline Yoldiella lucida & 3.3 & 0.2 & 93.9 & DF & Le & - & - \\
\hline Yoldiella frigida & 4.8 & 3.0 & 36.8 & DF & Le & - & - \\
\hline Thyasira spp. & 54.8 & 20.9 & 61.8 & DF & Le & - & $2-3$ \\
\hline Abra nitida & 12.0 & 6.7 & 44.1 & SDF & $\mathrm{Pl}$ & Sep-Oct & $2-7$ \\
\hline \multicolumn{8}{|l|}{ Sipunculida } \\
\hline Golfingia spp. & 29.1 & 16.6 & 43.0 & DF & Le & - & - \\
\hline -: no data & & & & & & & \\
\hline
\end{tabular}


Table 5. Summary of species disappering completely from $>30 \%$ of the stations in the periods $1987-88,1988-1989$ and $1989-90$ (respectively $1 \mathrm{yr}$ before, and 1 and $2 \mathrm{yr}$ after the bloom). Trophic level of each species are also indicated (C $=$ carnivore, $\mathrm{SDF}=$ surface deposit-feeder, $\mathrm{DF}=$ deposit-feeder, $\mathrm{SF}=$ suspension-feeder, $\mathrm{O}=$ omnivore, $\mathrm{H}=$ herbivore)

\begin{tabular}{|c|c|c|}
\hline $1987-88$ & $1988-89$ & $1989-90$ \\
\hline \multicolumn{3}{|l|}{$\begin{array}{l}\text { Cnidaria } \\
\text { Anthozoa spp. }\end{array}$} \\
\hline \multirow[t]{2}{*}{ Amaeana trilobata $(\mathrm{SDF})$} & $\begin{array}{l}\text { Polychaeta } \\
\text { Aphroditidae spp. juv. (C) } \\
\text { Eteone spp. (C) } \\
\text { Anaitides spp. juv. (C) } \\
\text { Syllidia armata (C) } \\
\text { Syllides longocirrata (C) } \\
\text { Sphaerosyllis hystrix (C) } \\
\text { Nephtydae spp. juv. (C) } \\
\text { Onuphis conchylega (C) } \\
\text { Pseudopolydora paucibranchiata (SDF) } \\
\text { Spiophanes spp. juv. (SDF) } \\
\text { Scolelepis squamata (SDF) } \\
\text { Scalibregma inflatum (DF) } \\
\text { Ophelina acuminata (DF) } \\
\text { Euclymene praetermissa (DF) } \\
\text { Myriochele spp. (DF) } \\
\text { Pectinaria auricoma (SDF) } \\
\text { Ampharete finmarchica (SDF) } \\
\text { Sosane sulcata (SDF) } \\
\text { Samytha sexcirrata (SDF) } \\
\text { Eupolymnia nesidensis (SDF) } \\
\text { Terebellides stroemi (SDF) } \\
\text { Chone infundibiliformis (SF) } \\
\text { Euchone spp. (SF) }\end{array}$ & $\begin{array}{l}\text { Polychaeta } \\
\text { Phyllodocidae sp. } 1 \text { (C) } \\
\text { Glycera alba (C) } \\
\text { Goniadella bobretzkii (C) } \\
\text { Nephtys ciliata (C) } \\
\text { Synelmis klatti (C) } \\
\text { Scalibregma inflatum (DF) } \\
\text { Pectinaria koreni (SDF) } \\
\text { Sabellides octocirrata (SDF) } \\
\text { Ampharete finmarchica (SDF) } \\
\text { Amaeana trilobata (SDF) }\end{array}$ \\
\hline & $\begin{array}{l}\text { Crustacea } \\
\text { Asterope norvegica (?) } \\
\text { Leucon nasica (SDF) }\end{array}$ & $\begin{array}{l}\text { Crustacea } \\
\text { Eudorella truncatula (SDF) } \\
\text { Tmetonyx cicada (?) } \\
\text { Calocaris macandrae (C) }\end{array}$ \\
\hline $\begin{array}{l}\text { Mollusca } \\
\text { Nucula delphinodonta (DF) } \\
\text { Modiolus phaseolinus (SF) }\end{array}$ & $\begin{array}{l}\text { Mollusca } \\
\text { Entalina quinquangularis (DF) } \\
\text { Philine scabra (C) } \\
\text { Natica alderi (C) } \\
\text { Nucula tumidula (DF) } \\
\text { Yoldiella lucida (DF) }\end{array}$ & $\begin{array}{l}\text { Mollusca } \\
\text { Nucula sulcata (SDF) } \\
\text { Yoldiella frigida (DF) } \\
\text { Cerastoderma minimum (SF) }\end{array}$ \\
\hline & $\begin{array}{l}\text { Sipunculida } \\
\text { Phascolion strombi (DF) } \\
\text { Phoronida } \\
\quad \text { Phoronis muelleri (SF) }\end{array}$ & \\
\hline $\begin{array}{l}\text { Echinodermata } \\
\text { Brissopsis lyrifera (DF) }\end{array}$ & $\begin{array}{l}\text { Echinodermata } \\
\text { Amphiura chiajei (O) } \\
\text { Amphiura spp. juv. (O) } \\
\text { Ophiura sarsi (C) } \\
\text { Ophiura spp. juv. (C) }\end{array}$ & $\begin{array}{l}\text { Echinodermata } \\
\qquad \text { Echinocardium flavescens (DF/H) }\end{array}$ \\
\hline
\end{tabular}

numbers. This could be the result of a continuous effect of Chrysochromulina polylepis and indicates that an equilibrium is still not reached.

The species in Table 5 were all characterised by a low number of individuals and must be considered as rare species in the study area. In benthic surveys most attention is traditionally given to the numerically dominant species while rare species are usually considered of minor interest. The main reason for this is that rare species contribute little to the total abundance and biomass and are considered as mere random members of the communities. From 2 to 3 times more rare species vanished after the bloom event (1988-89) compared to the year before (1987-88) and the year after (1989-90), which indicates that investigation of rare species may probably be of interest in studies of changes in benthic 
Table 6. Ranking of the 10 most numerous species in the survey area each year

\begin{tabular}{|lrrrc|}
\hline Species & 1987 & 1988 & 1989 & 1990 \\
\hline Heteromastus filiformis & 1 & 1 & 1 & 1 \\
Exogone hebes & 2 & 2 & 2 & 2 \\
Oligochaeta & 3 & 3 & 3 & 3 \\
Exogone verugera & 4 & 4 & 5 & 9 \\
Nemertini & 5 & 7 & 4 & 4 \\
Thyasira spp. & 6 & 8 & 7 & \\
Paramphinome jeffreysii & 7 & 10 & & \\
Melinna cristata & 8 & 6 & & \\
Sabellidae spp. & 9 & 5 & & \\
Eclysippe vanelli & 10 & 9 & 7 & 6 \\
Spiophanes kröyeri & 10 & 9 & 8 & \\
Caulleriella spp. & 6 & & & \\
Aricidea spp. & 10 & & & \\
Tharyx spp. & 8 & 5 & & \\
& & & & \\
\hline
\end{tabular}

communities. All trophic levels seem to be affected, and many juveniles disappeared in 1989 (Table 5). A similar disappearance of juveniles was not observed before and 2 yr after the bloom which may indicate a disturbance in recruitment in 1989.

Ranking of the 10 most abundant species in the survey area from $1987-90$ gave a total list of 14 species (Table 6). The 2 polychaetes Heteromastus fillformis and Exogone hebes and Oligochaeta were the most numerous taxa during these $4 \mathrm{yr}_{\text {; }}$ however, thelr individual rank remained unaffected by the bloom. The next 2 taxa, the polychaete Exogone verugera and the group Nemertini, exhibit some adjustments in abundance over time, but the first taxa to show apparent changes in rank order were the bivalve Thyasira spp. and the polychaetes Paramphinome jeffreysu, Sabelldae spp. and Melinna cristata. In the period 1988-1989 these 4 taxa were not represented among the top ranked species (Table 6) and their absence was the most obvious change. In the SIMPER analysis (Table 4) these 4 species were also identified as key species responsible for the observed change in faunal simllarity within the study area from 1988 to 1989

The $z$-statistics for each individual station each year are given in Fig. 9. Between 1988 and 1989 a sıgnificant reduction in the $z$-value was found at all sites except Stns $53 \& 55$. The most obvious, negative changes were found at stations situated in accumulation areas illustrated by an apparent reduction in the $z$-value. The negative $z$-value found at all stations between 1988 and 1989 illustrate that the majority of the species showed a reduction in abundance in this period.

From 1986 to 1987 and 1987 to 1988 the proportion of gaining and losing species was almost the same, but from 1988 to 1989 a significant increase in losing species and a significant decrease in gaining species was observed (Fig. 10). The following year an opposite
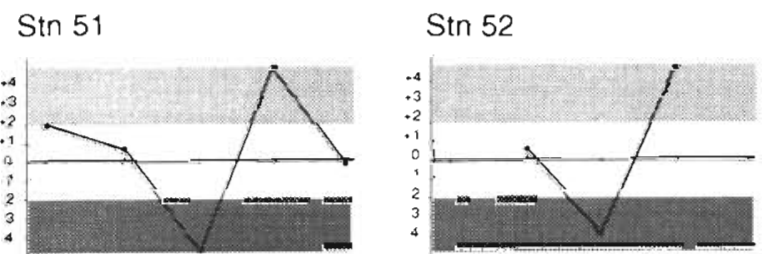

$\operatorname{Stn} 53$

$\operatorname{Stn} 54$
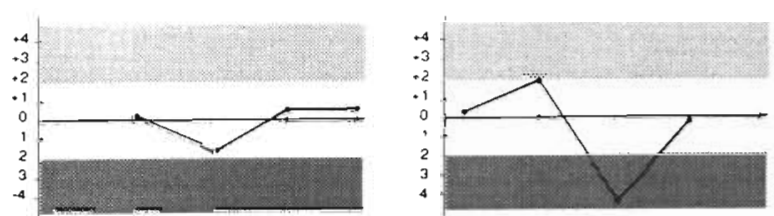

$\operatorname{Stn} 55$

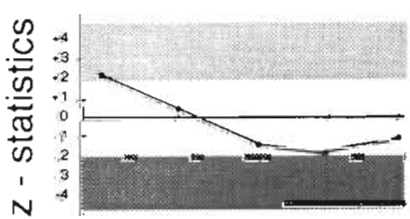

$\operatorname{Stn} 57$

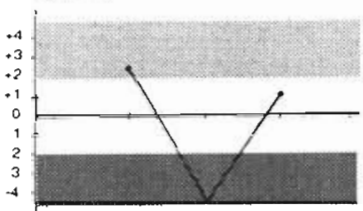

$\operatorname{Stn} 58$

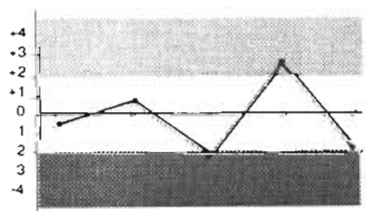

$\operatorname{Stn} 59$

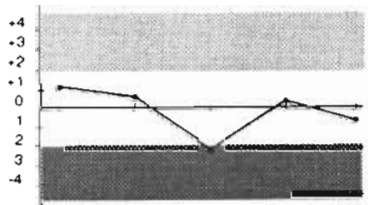

$\operatorname{Stn} 60$

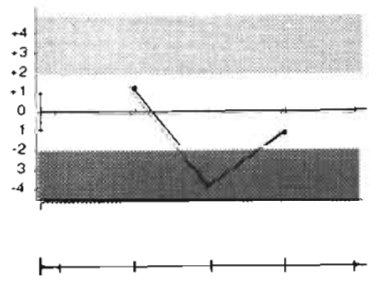

1986-87 $198788 \quad 1988-89 \quad 198990 \quad 1990-9$

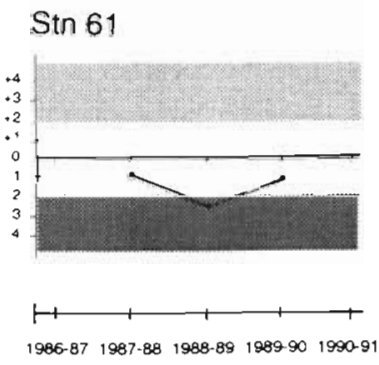

Fig 9. The $z$-statistics from Wilcoxon matched-paurs s.gnedranks tests of signuficance of changes in the number of gaining and losing species at each station The number of observations are the total number species at each station between years $(1986-87,1987-88$ etc ). The light-shaded area indicate a significant positive change (significant increase of gaining species, $z>+196, p<0.05$ ) whlle the darkshaded area indicate a significant negative change (significant increase of losing species, $z<-196, p<0$ 05) The non-shaded area between the $z$-values \pm 196 represent the area of non-signiticant change ( $\mathrm{p}>005)$

pattern was apparent with a high proportıon of gaining species and fewer losing species until the system again stabilised with an almost similar proportion of species in each group in 1990-91. The curves for gaining and losing are, as expected, nearly inversely related. The proportion of neutral species was low during the entire perıod and displayed no significant changes. 


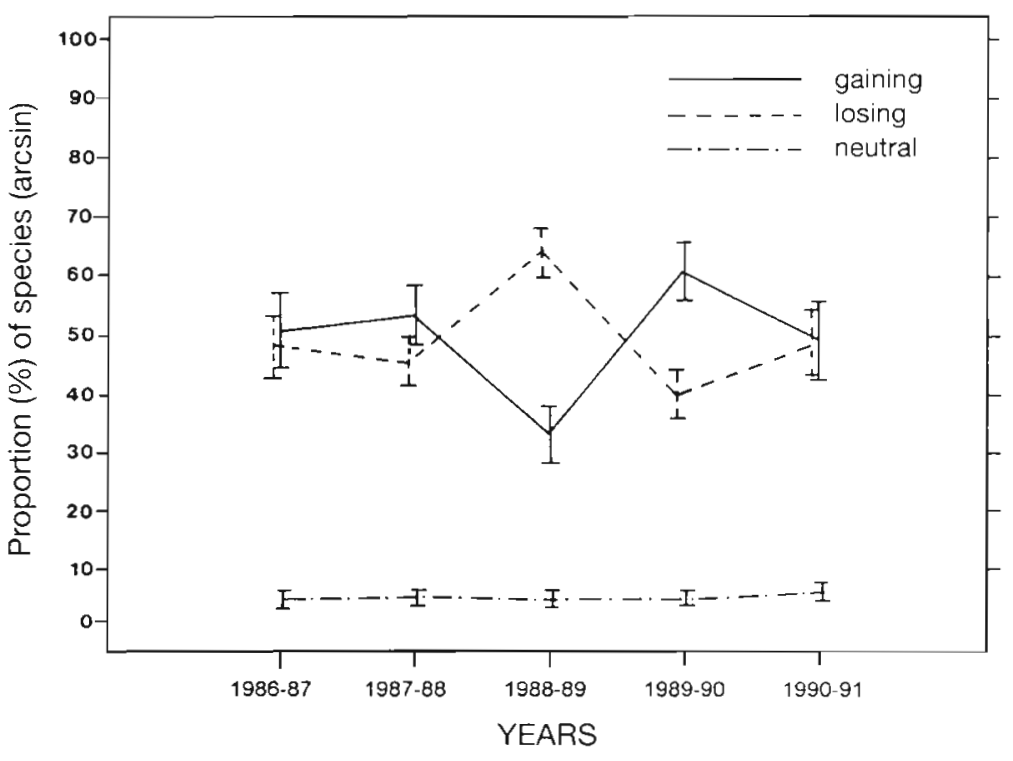

Fig. 10. Proportion of gaining, losing and neutral species between years to the total number of species. For each of the 3 categories the $95 \%$ confidence intervals, calculated from the mean square values based on a 1-way ANOVA, is given

\section{DISCUSSION}

\section{Possible causes for the observed changes in fauna}

A simultaneous reduction in both number of species and abundance within the study area indicate that the area was affected by a common factor of disturbance. Comparable reductions in number of species and abundance of soft-bottom fauna were also reported by Oug \& Rygg (unpubl.) from an area about $120 \mathrm{~km}$ southeast of Jøssingfjord. This indicates that the changes occurred over large areas. The bloom of the toxic alga Chrysochromulina polylepis was the only known disturbance of importance in the study period. At the same time other possible factors responsible for the observed faunal perturbation cannot be excluded. The main extrinsic factors of importance for subtidal benthic fauna are probably water temperature and food input (Buchanan \& Moore 1986a, b, Pearson et al. 1986, Grebmeier et al. 1989). Changes in the benthic communities could also be a result of predationinterference, changes in sediment composition or sediment re-working.

The water temperatures at $150 \mathrm{~m}$ depth between 1975 and 1992 from the 2nd quarter each year at Lista, about $35 \mathrm{~km}$ southeast of Jøssingfjord, are shown in Fig. 11. The data represent yearly minimum temperatures, which are an important reason for fluctuations in benthic fauna (Buchanan et al. 1978). There was an abrupt discontinuity in temperature between 1978 and 1980 and between 1987 and 1988, when the temperature was about $2{ }^{\circ} \mathrm{C}$ below the mean temperature of $6.0^{\circ} \mathrm{C}$. Buchanan et al. (1978) pointed out that in warmer years following a period of cold winters there was a replacement in the top ranking of some larger species by small species of polychaetes, accompanied by a rise in total number of individuals present. Similar trends were observed by Pearson et al. (1986) in their study in Loch Linnhe and Loch Eil, and they suggested that climatic fluctuations acted on the spawning success and subsequent recruitment of particular species. Souprayen et al. (1991) further suggested that during cool periods, a developing mismatch between peak zooplankton and phytoplankton productivity may increase the supply of carbon to the benthos with a decrease in number of species and an increase in abundance and biomass as a result. From

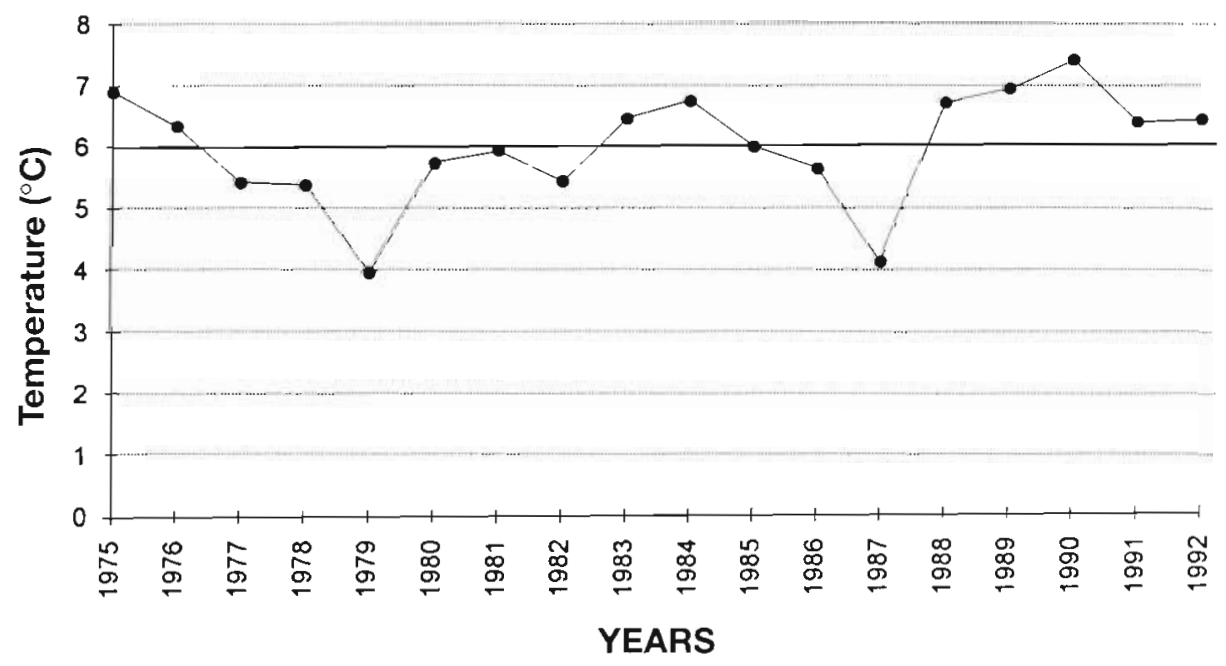

Fig. 11. Recordings of temperature from the 2 nd quarter each year from 1975 to 1992 at $150 \mathrm{~m}$ depth outside Lista $\left(58^{\circ} 01^{\prime} \mathrm{N} ; 6^{\circ} 32^{\prime} \mathrm{E}\right)$. Solid line indicate the average temperature. Source: Institute of Marine

Research, Bergen, Norway 
the Jøssingfjord area neither a replacement of the top ranked species by smaller polychaetes nor an increase in abundance, such as observed in the studies above, were detected. This suggests that the temperature anomaly recorded in the Jøssingfjord area from 1987 to 1988 is not an explanation of the observed changes in fauna from 1988 to 1989

Several studies from the North Sea and Skagerrak have suggested a trend in the last 5 to $10 \mathrm{yr}$ of increasing phytoplankton production and sedimentation of organic material to the bottom (Buchanan \& Moore 1986a, b, Josefson 1990, Austen et al. 1991, Colebrook 1992, Josefson \& Jensen 1992) resulting in a general increase of benthic abundance and biomass. In the Jøssingfjord area a reduced faunal abundance was found from 1988 to 1989 which could not be a response to a possible increase of organic material to the area.

Reduction in abundance of species may also result from increased predation. Main predators are often taken to be carnivorous benthic invertebrates (Peterson 1979) and various species of fish (Le Mao 1986). In the Jøssingfjord area none of the larger predatory macrofauna like nemertean worms and the polychaetes Glycera spp., Goniada spp. and Lumbrineris spp. showed an increase in abundance. In fact, reduced abundances were found for most carnivorous species between 1988 and 1989 .

Fish have been caught as part of a monitoring programme with a beam trawl in the same area as the benthic grab samples (Miljøplan A/S, Sandvika, Norway, unpubl.). Common fish species in the area, which are known to feed on soft-bottom fauna, are cod Gadus morhua, haddock Melanogrammus aeglefinus, plaice Pleuronectes platessa, witch Glyptocephalus cynoglossus, long rough dab Hippoglossus platessoides, lemon sole Microstomus kitt and four-bearded rockling Rhinonemus cimbrius. The beam trawl catches indicated that no changes in number of fish species or their individual abundances have taken place in the study area in the last 10 yr. Fluctuations in fish predation are therefore not likely to be a possible explanation for the observed changes in the benthic communities from 1988 to 1989 .

Sampling of sediments revealed no apparent changes in the sediment parameters during the study period. Likewise no increase, but rather a decrease, in abundance of deposit-feeders in the study area was noticed from 1988 to 1989 , which rules out explanations related to the trophic-group amensalism hypothesis (Rhoads \& Young 1970).

Deoxygenation has been suggested as one of the main reasons for kills of fish and benthic invertebrates following blooms of Gyrodinium aureoleum (Tangen 1977, Boalch 1984). However, the Jøssingfjord area is an open and exposed part of the coastline, and it is unlikely that water ever becomes deoxygenated. Quarterly oxygen measurements a few meters above the sea bottom in a deep and comparatively sheltered part of the study area (Dyngadypet, $160 \mathrm{~m}$ depth; see Fig. 2), in the years 1978 to 1984, always gave values higher than $4.5 \mathrm{mg} \mathrm{O}_{2} \mathrm{l}^{-1}$ (Miljøplan $\mathrm{A} / \mathrm{S}$, unpub1.). The total algal biomass contribution from Chrysochromulina polylepis was very small due to the small size of the algae. Lindahl (1991), in his study of the C. polylepis bloom in the Gullmarsfjord on the west coast of Sweden, showed that the alga contributed only about $10 \%$ of the total annual primary production.

None of the factors mentioned above are plausible explanations for the observed reductions in number of species and abundance between 1988 and 1989. In the same period the study area was exposed to a comprehensive toxic bloom, and it is natural to see the faunal perturbation in connection with the bloom of Chrysochromulina polylepis.

\section{Possible mechanisms of impact from Chrysochromulina polylepis}

The impact of a toxic planktonic alga on benthos below the euphotic zone obviously requires sedimentation of the toxic alga or particles containing the toxin to the bottom. Several studies indicate that sinking particles, once they have left the surface layer, reach the seabed comparatively rapidly (Graf et al. 1983, Rice et al. 1986, Kiørboe et al. 1990). In the Gullmarsfjord Lindahl (1991) found that most of the Chrysochromulina polylepis population sedimented within $72 \mathrm{~h}$. The algal material caught in the sediment traps during this period was aggregated (Lindahl \& Rosenberg 1989).

Several species of diatoms, especially older and nutrient-depleted populations, are well known to become sticky by mucus secretion and form aggregates (Kranck \& Milligan 1988, Alldredge \& Gotschalk 1989, Kiørboe et al. 1990). Aggregation increases the size and density and hence the sinking rate of the phytoplankton cells considerably (Smetacek 1985, Nicolaisen \& Christensen 1986). It is unknown whether similar mechanisms exist for Chrysochromulina polylepis, but the high density of algal cells observed during the bloom makes it likely that aggregates were formed during sedimentation of the algae, and thus enabled a more rapid sedimentation. The observed mass sedimentation (Lindahl 1991) and aggregation (Lindahl \& Rosenberg 1989) of C. polylepis indicate that these mechanisms were operative.

Another possible pathway for algal biomass to reach the bottom is through sedimentation of fecal pellets from herbivorous zooplankton. If the algae were 
consumed by zooplankton, remains of algal material would probably reach the bottom fast due to high sinking rates of fecal pellets, up to over $200 \mathrm{~m} \mathrm{~d}^{-1}$ (Smayda 1969, Turner 1977).

Granéli et al. (1993) observed that during much of the time the Chrysochromulina polylepis bloom was virtually monospecific, and that the few other planktonic algae and zooplankton present were in poor condition. It was also demonstrated that depths with high concentrations of the toxic algae were almost free from ciliates and copepods, the potential predators for C. polylepis (Dahl et al. 1989, Nielsen et al. 1990).

In temperate coastal waters, copepods only consume a small fraction of the spring bloom primary production (Falkowski et al. 1988, Smith \& Lane 1988, Nielsen \& Richardson 1989), and at the peak of the Chrysochromulina polylepis bloom it is unlikely that copepods could efficiently exploit the increased algal biomass. During the bloom it also appears that potential grazers avoided waters rich in toxic phytoplankton, and it is therefore possible that a main part of the toxic algal cells sedimented ungrazed to the sea floor. The toxicity of C. polylepis was shown to last for 4 to $5 \mathrm{wk}$ and could be transferred to other organisms (Pedersen et al. 1992, Oug \& Rygg unpubl.). Increased zooplankton mortality and increased sedimentation of dead zooplankton following ingestion of the toxic algae therefore may be a possible pathway for transportation of toxic material to the benthic fauna.

In the soft bottom communities species from all trophic levels were reduced after the toxic bloom. Experiments have shown a rapid response of benthic animals to sedimentation during phytoplankton blooms and an increase in benthic metabolism at 6 to $7 \mathrm{~cm}$ depth in sediments within $1 \mathrm{~d}$ after sedimentation (Graf 1987). Several species of polychaetes (e.g. Heteromastus spp., Capitella spp., Terebellides stroemi and Trichobranchus glacialis) are often observed with algal fragments in their guts (Fauchald \& Jumars 1979), suggesting that phytoplankton reaching the bottom can probably be utilised directly indicating that a rapid transfer of toxins, even to deposit-feeders, is possible.

However, in the Jøssingfjord area many species in the soft-bottom communities remained unaffected. Studies from shallow waters after the Chrysochromulina polylepis bloom also showed distinct effects on some species while closely related species were unaffected. Among bivalves, mortality was high, e.g. in the horse mussel Modiolus modiolus and saddle oyster (Family Anomiidae), whereas the common mussel Mytilus edulis and the edible oyster Ostrea edulis appeared to be resistant (Berge et al. 1988, Underdal et al. 1989, Pedersen et al. 1992). Selective mortality of littoral fauna was also reported by Southgate et al. (1984) from SW Ireland following a bloom of the toxic dinoflagellate Gyrodinium aureolum. In soft sediments toxic effects and mass mortalities of lugworm populations Arenicola marina in South Wales, also related to a bloom of G. aureolum, were described by Olive \& Cadnam (1990). They also found that other species from the same trophic level as the lugworm remained unaffected.

Insufficient information is available on diet and digestive physiology of most soft-bottom species. One possible explanation for differences in toxic effects between species is that most species are highly selective in their choice of diet and that only some of the food available was toxic. It is also known that items selected for ingestion can be processed in different ways by the different species (Jumars et al. 1984), which means that only a few species ingesting the same kind of particles may experience toxic effects.

Subsequent to the bloom, no opportunistic species increased in abundance. The sieves used in the study had a $1 \mathrm{~mm}$ mesh size, and underestimation of recruitment of opportunists therefore is possible. If a time lag of 0.5 to $1 \mathrm{yr}$ is allowed for sieve recruitment, which according to studies of Buchanan \& Warwick (1974), Buchanan et al. (1986) and Josefson (1986) should be sufficient for most of the current species, faunasamples from 1990, which is almost $2 \mathrm{yr}$ after the bloom event, should contain any dominant opportunistic species, if present. No increase, but rather a decrease of the initially abundant opportunistic species (e.g. Heteromastus filiformis and Spiophanes kroyeri) was detected in the samples from 1989 and 1990.

In 1989 a deficiency of juveniles was observed in the Jøssingfjord area compared to the years before and after the bloom. In a study about $120 \mathrm{~km}$ southeast of Jøssingfjord, disturbance in recruitment was suggested as a possible reason for lack of faunal recovery subsequent to the bloom (Pedersen et al 1989b). Laboratory experiments have shown toxic effects of Chrysochromulina polylepis on eggs and larvae of benthic macrofauna (Granmo et al. 1988, Nielsen \& Strømgren 1991) and nauplii of crustaceans (Edvardsen \& Paasche 1992). Eggs and larvae of a large number of bottom fauna species are found in the euphotic zone for shorter or longer periods and negative effects due to high density populations of the toxic algae in this zone therefore are possible. In water samples collected during the bloom, free toxins were also found in the water masses (Yasomoto et al. 1990).

\section{Changes in faunal composition following the algal bloom}

Disturbance in benthic communities normally induces changes in number of species and individuals 
which most often results in a change in diversity (Gray 1979, Rapport et al. 1985). A typical community response to stress, after a possible short period of stimulation, is a reduction in number of species, an increase in total abundance due to an increase of opportunistic species and a corresponding reduction in diversity (Pearson \& Rosenberg 1978). After the Chrysochromulina polylepis bloom a simultaneous reduction in both number of species and abundance occurred, and diversity indices, with few exceptions, showed no changes from 1988 to 1989 (Table 3). Also Pielou's evenness index remained high or even increased following the bloom event. Application of diversity indices therefore was not very suitable for measuring the perturbation caused by $C$. polylepis. Rosenberg (1976) pointed out that diversity, when used alone, was useless as a measure of environmental impact. Changes in species richness is often a simpler and better parameter in assessing disturbance in benthic communities.

In a study of benthic faunal response to copper, lead and zinc pollution in several recipients in Norway, Rygg (1986) described a similar situation with a reduction in both number of species and abundance and showed no dominance of opportunistic species at sites close to industrial outlets. It is possible that this drop in both number of species and individuals when exposed to Chrysochromulina polylepis or heavy metals is a typical community response for exposure to toxic agents. This may indicate that the classical response model of a benthic community exposed to pollution with a reduction in number of species and an increase in abundance of opportunistic species, originally described from studies of organic pollution, is not appropriate when benthic fauna is exposed to toxic substances.

Altogether 18 taxa were isolated as the most affected faunal elements in the Jøssingfjord area following the bloom (Table 4). The polychaetes Diplocirrus glaucus and Prionospio spp. and the bivalves Thyasira spp. and Abra nitida were also indicated by Oug \& Rygg (unpubl.) as some of the most affected after the bloom event. Their stations were in shallower areas with a mean depth of $47 \mathrm{~m}$, compared to the stations in the Jøssingfjord area with a mean depth of $141 \mathrm{~m}$. Differences in depth results in different benthic communities and sedimentation conditions and thus there are few common species affected in the 2 study areas

Allocation of species to the categories 'gaining' and 'losing' due to changes in abundance from yearto-year gave a good description of the perturbation following the bloom (Fig. 10). The method is simple and objective and also permits statistical testing for evaluating changes. No subjective selection of species is performed because all species, sites and years are taken into consideration.
Selye (1973) suggested a model of the response of an individual organism to stress-producing factors, stressors, known as the General Adaptation Syndrome or biologic stress syndrome. The model for a single application of a stressor, in contrast to a continuous application of a stressor, is shown in Fig. 12 which is a simplification of the model given in Selye (1973) and Rapport et al. (1985). A single application of a stressor (vertical arrow) may lead to a measurable response within the organism, the alarm reaction (A), followed by compensation to the stressor, the stage of resistance (B), and finally return to normal level of activity (Fig. 12).

The diagram resulting from separation into gaining and losing species (Fig. 10) of the soft-bottom communities in the Jøssingfjord area clearly resembles Selye's model for the response of an organism to a single application of a stressor. From 1988 to 1989 a significant drop in the proportion of gaining species and a significant increase of losing species was observed. This reflects a considerable mortality within the populations in the period following the toxic bloom, comparable to the alarm reaction (A) in Selye's model (Fig. 12). From 1989 to 1990 the reverse trend was observed with a significant increase of gaining species and a significant drop in losing species. After this stage of resistance (B), following the terminology of Selye, the communities finally in 1990 to 1991 returned to the expected distribution between gaining and losing species when there was no community perturbation. This method for separation into 'Gaining' and 'Losing' species (GL-method), according to changes in number of individuals within species following exposure to stress, can be a possible extrapolation of Selye's stress model to the community level. Gray (1989) has suggested that Selye's model is not appropriate for describing effects at the community level, but using the GL-method proposed above may permit application of the model even at this level.

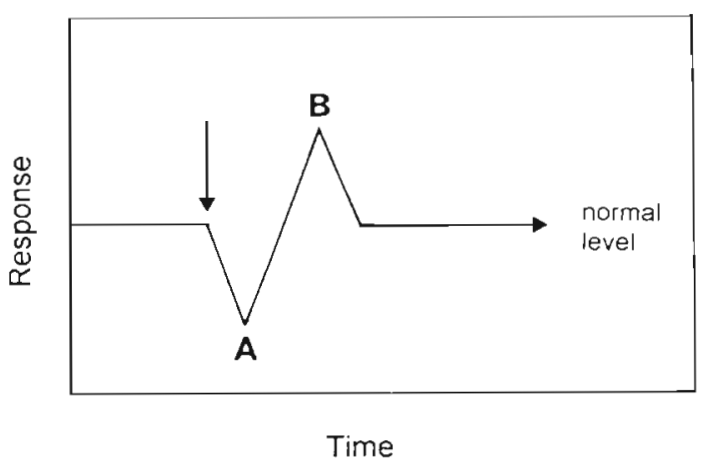

Fig. 12. Simplification of Selye's General Adaption Syndrome model for a single application of a stressor (vertical arrow) to an organism. A: alarm reaction; B: stage of resistance 
Separation into the categories of gaining, losing and neutral species was also applied by Buchanan et al. (1978) in their study of benthic communities off Northumberland, but they took only numerically dominant species and examined trends not from year-toyear but cumulatively over a period of 5 years. Oug \& Rygg (unpubl.), in their investigation of effects of Chrysochromulina polylepis on soft bottom communities, also found that most species decreased in abundance, which is in accordance with the first phase of community perturbation described from the Jøssingfjord area.

\section{Concluding remarks}

The study of soft-bottom communities in the Jøssingfjord area suggests effects of Chrysochromulina polylepis down to a depth of $180 \mathrm{~m}$. Observations directly relating the faunal changes and toxic algae are lacking and only few other comparable data sets, although indicating toxic effects, are available. Only through experiments, probably in mesocosms, one may establish plausible connections between sedimentation of the alga and adverse effects on softbottom communities.

Acknowledgements. I thank Titania A/S for permission to use data from monitoring surveys performed on their behalf while the author was employed by A/S Miljøplan. Thanks are due to A/S Miljøplan and particularly participants in the monitoring programme: F. Aarefjord, P. E. Iversen, R. Jaques, T. Jensen, S. Kolstad, 1. D. Saanum and A. M. Skullerud, as well as Titania's boat crew and laboratory personnel. I also thank J. S. Gray for discussions and critical review of the manuscript and M. I. Abdullah, K. Hylland and E. Oug for most helpful comments. Parts of this study was supported by a grant from the Norwegian Research Council, which is gratefully acknowledged.

\section{LITERATURE CITED}

Austen, M. C., Buchanan, J. B., Hunt, H. G., Josefson, A. B., Kendall, M. A. (1991). Comparison of long-term trends in benthic and pelagic communities of the North Sea. J. mar. biol. Ass. U.K 71. 179-190

Alldredge, A. L., Gotschalk, C. C. (1989). Direct observations of the mass flocculation of diatom blooms: characteristics, settling velocities and formation of diatom aggregates. Deep Sea Res. 36: 159-171

Berge, J. A., Green, N., Rygg, B. (1988). The invasion of the planktonic algae Chrysochromulina polylepis along the coast of southern Norway in May-June 1988. Acute effects on coastal biota. Summary report. NIVA-report 2175: 1-44

Boalch, G. T. (1984). Algal blooms and their effects on fishing in the English Channel. Hydrobiologia 116/11.7: 449-452

Bray, J. R, Curtis, J T. (1957). An ordination of the upland forest communities of southern Wisconsin. Ecol. Monogr. 27: $325-349$
Buchanan, J. B., Warwick, R. M. (1974). An estimate of benthic macrofaunal production in the of fshore mud of the Northumberland coast. J. mar. biol. Ass. U.K. 54: 197-222

Buchanan, J. B., Sheader, M., Kingston, P. F. (1978). Sources of variability in the benthic macrofauna off the South Northumberland Coast, 1971-1976. J. mar. biol. Ass. U.K. 58: $191-209$

Buchanan, J. B., Moore, J. J. (1986a), Long-term studies at a benthic station of the coast of Northumberland. Hydrobiologia 142: 121-127

Buchanan, J. B., Moore, J. J. (1986b). A broad review of variability and persistence in the Northumberland benthic fauna - 1971-85. J. mar. biol. Ass. U.K. 66: 641-657

Buchanan, J. B., Brachi, R., Christie, G., Moore, J. J. (1986). An analysis of a stable period in the Northumberland benthic fauna-1973-80. J. mar. biol. Ass. U.K. 66: 659-670

Clarke, K. R., Green, R. H. (1988). Statistical design and analysis for a 'biological effects' study. Mar. Ecol. Prog. Ser. 46: 213-226

Colebrook, J. M. (1992). Continuous plankton records: the North Sea in the 1980s. ICES mar. Sci. Symp. 195: 243-248

Dahl, E., Lindahl, O., Paasche, E., Throndsen, J. (1989). The Chrysochromulina polylepis bloom in Scandinavian waters during spring 1988. In: Cosper, E. M., Bricelj, M., Carpenter, E. J. (eds.) Novel phytoplankton blooms: causes and impacts of recurrent brown tides and other unusual blooms. Springer, Berlin, p. 383-405

Dundas, I., Johannesen, O. M., Berge, G., Heimdal, B. (1989). Toxic algal bloom in Scandinavian waters, May-June 1988. Oceanology 2: 9-14

Edvardsen, B., Paasche, E. (1992). Two motile stages of Chrysochromulina polylepis (Prymnesiophyceae): morphology, growth, and toxicity. J. Phycol. 28: 104-114

Falkowski, P. G., Flagg, C. N., Rowe, G. T., Smith, S. L., Whitledge, T. E., Wirick, C. D. (1988). The fate of a spring phytoplankton bloom: export or oxidation. Cont. Shelf Res. 8: $457-484$

Fauchald, K., Jumars, P. A. (1979). The diet of worms: a study of polychaete feeding guilds. Oceanogr, mar. Biol. A. Rev. 17: $193-284$

Field, J. G., Clark, K. R., Warwick, R. M. (1982). A practical strategy for analysing multispecies distribution patterns. Mar. Ecol. Prog. Ser. 8: 37-52

Gauch, G. H. (1982). Multivariate analysis in community ecology. Camb. Stud. Ecol. 1: 1-298

Gjøsæter, J. (1988). Algeoppblomstringen i Skagerrak mai 1988. Effekter på fisk og bunnfauna på Sørlandskysten. Vann 3B: $524-535$

Graf, G. (1987). Benthic energy flow during a simulated autumn bloom sedimentation. Mar. Ecol. Prog. Ser. 39: 23-29

Graf, G., Schultz, R., Peinert, R., Meyer-Reil, L.-A. (1983). Benthic responce to sedimentation events during autumn to spring at a shallow-water station in the western Kiel Bight. Mar. Biol. 77: 235-246

Granéli, E., Paasche, E., Maestrini, S. Y (1993). Three years after the Chrysochromulina polylepis bloom in Scandinavian waters in 1988: some conclusions of recent research monitoring. In: Smayda, T. J., Shimizu, Y (eds.) Toxic phytoplankton blooms in the sea. Proceedings of the 5 th International Conference on Toxic Marine Phytoplankton, Newport, R.I., 28 October-1 November, 1991. Elsevier, Amsterdam, p. 25-32

Granmo, A., Havenhand, J., Magnusson, K., Svane, I. (1988). Effects of the planktonic flagellate Chrysochromulina polylepis Manton et Park on fertilization and early development of the ascidian Ciona intestinalis (L.) and the blue mussel Mytilus edulis L. J. exp. mar. Biol. Ecol. 124: 65-71 
Gray, J. S. (1979). Pollution-induced changes in populations. Phil. Trans. R. Soc. Lond. B 286: 545-561

Gray, J. S. (1989). Effects of environmental stress on species rich assemblages. Biol. J. Linn. Soc. 37: 19-32

Grebmeier, J. M., Feder, H. M., McRoy, C. P. (1989). Pelagicbenthic coupling on the shelf of the northern Bering and Chukchi Seas. II. Benthic community structure. Mar. Ecol. Prog. Ser. 51: 253-268

Hartmann-Schröder, G. (1971). Annelida, Borstenwürmer, Polychaete. Tierwelt Dtl. 58: 1-594

Hill, M. O., Gauch, G. H. (1980). Detrended correspondence analysis: an improved ordination technique. Vegetatio 42 : $47-58$

Jongman, R. H. G., Ter Braak, C. J. F., Van Tongeren, O. F. R. (1987). Data analysis in community and landscape ecology. Pudoc, Wageningen, p. 1-299

Josefson, A. B. (1981). Persistence and structure of two deep macrobenthic communities in the Skagerrak (west coast of Sweden). J. exp. mar. Biol. Ecol. 50: 63-97

Josefson, A. B. (1986). Temporal heterogenity in deep-water soft sediment benthos - an attempt to reveal temporal structure. Estuar. coast. Shelf Sci. 23: 147-169

Josefson, A. B. (1987). Large-scale patterns of dynamic in subtidal macrozoobenthic assemblages in the Skagerrak: effects of a production-related factor? Mar. Ecol. Prog. Ser. 38: $13-23$

Josefson, A. B. (1990). Increase of benthic biomass in the Skagerrak-Kattegat during the 1970 s and 1980 s - effects of organic enrichment? Mar. Ecol. Prog. Ser, 66: 117-130

Josefson, A. B., Jensen, J. N. (1992). Growth patterns of Amphiura filiformis support hypothesis of organic enrichment in the Skagerrak-Kattegat area. Mar. Biol. 112: $615-624$

Jumars, P. A., Newell, R. C., Angel, M. V., Fowler, S. W., Poulet, S. A., Rowe, G. T., Smetacek, V. (1984). Detritivory. In: Fasham, M. J. R. (ed.) Flows of energy and materials in marine ecosystems. Plenum Press, New York, p. 685-693

Kiørboe, T., Andersen, K. P., Dam, H. G. (1990). Coagulation efficiency and aggregate formation in marine phytoplankton. Mar. Biol. 107: 235-245

Kranck, K., Milligan, T. G. (1988). Macroflocs from diatoms: in situ photography of particles in Bedford Basin, Nova Scotia. Mar. Ecol. Prog. Ser. 44: 183-189

Krumbein, W. C., Pettijohn, F. J. (1938). Manual of sedimentary petrography. Appleton Century Croft, New York, p. $1-549$

Lance, G. N., Williams, W. T. (1967). A general theory of classificatory sorting strategies. I. Hierarchical systems. Comput. J. 9: 373-380

Le Mao, P. (1986). Feeding relationships between the benthic infauna and the dominant benthic fish of the Rance Estuary (France). J. mar. biol. Ass. U.K. 66: 391-401

Lindahl, O. (1991). Dynamics and sedimentation of algal blooms in the Gullmarsfjord in 1988. In: Wassmann, P., Heiskanen, A. S., Lindahl, O. (eds.) Sediment trap studies in the Nordic countries. 2. Symposium Proceedings, Kristineberg Marine Biological Station, Sweden, 21-25 November 1990. Nurmiprint, Nurmijärvi, p. 190-202

Lindahl, O. Dahl, E. (1990). On the development of the Chrysochromulina polylepis bloom in the Skagerrak in May-June 1988. In: Granéli, E., Sundstrøm, B., Edler, E., Anderson, D. M. (eds.) Toxic marine phytoplankton. Elsevier, London, p. 189-194

Lindahl, O., Rosenberg, R. (1989). Algoppblomningen av Chrysochromulina polylepis ved svenska västkusten 1988: fysisk-kemiska, biologiska och effektrelaterade studier. Naturvårdsverket Rapport 3602: 1-71
Margalef, R. (1958). Temporal succession and spatial heterogenity in phytoplankton. In: Buzzati-Traverso, A. A. (ed.) Perspectives in marine biology. University of California Press, Los Angeles, p. 323-349

Nicolaisen, W., Christensen, H. (1986). Pelagic turnover and transport to the bottom of particulate organic material in the Northern Øresund. Ophelia 26: 317-332

Nielsen, M. V., Strømgren, T (1991). Shell growth response of mussels (Mytilus edulis) exposed to toxic microalgae. Mar. Biol. 108: 263-267

Nielsen, T. G., Kiørboe, T., Bjørnsen, P. K. (1990). Effects of a Chrysochromulina polylepis surface bloom on the planktonic community. Mar. Ecol. Prog. Ser. 62: 21-35

Nielsen, T. G., Richardson, K. (1989). Food chain structure of the North Sea plankton communities: seasonal variations of the role of the microbial loop. Mar. Ecol. Prog. Ser. 56: $75-87$

Olive, P. J. W., Cadnam, P. S. (1990). Mass mortalities of the lugworm on the South Wales coast: a consequence of algal bloom? Mar. Pollut. Bull. 21: 542-545

Olsgard, F., Hasle, J. R. (1993). Impact of waste from titanium mining on benthic fauna. J. exp. mar. Biol. Ecol. (in press)

Pearson, T. H. (1971). Studies on the ecology of the macrobenthic fauna of Lochs Linnhe and Eil, west coast of Scotland. II. Analysis of the macrobentic fauna by comparison of feeding groups. Vie et Milieu suppl. 22: 53-91

Pearson, T. H., Rosenberg, R. (1978). Macrobenthic succession in relation to organic enrichment and pollution of the marine environment. Oceanogr. mar. Biol. A. Rev. 16: 229-311

Pearson, T. H., Duncan, G., Nuttall, J. (1986). Long term changes in the benthic communities of Loch Linnhe and Loch Eil (Scotland). Hydrobiologia 142: 113-119

Pedersen, A., Wikander, P. B., Oug, E., Green, N. (1989a). Invasjon av planktonalgen Chrysochromulina polylepis. Virkninger på organismesamfunn langs kysten. NIVA's undersøkelser i november 1988. NIVA-report 2233: $1-182$

Pedersen, A., Oug, E., Green, N. (1989b). Oppblomstring av planktonalgen Chrysochromulina polylepis. Gjenvekst av organismesamfunn langs kysten. NIVA's undersøkelser i juni 1989. Hovedrapport. NIVA-report 2395: 1-92

Pedersen, A., Walday, M., Oug, E. (1992). Chrysochromulina polylepis - en katastrofe? Statlig program for forurensnings-overvåking 475: 1-33

Peterson, C. H. (1979). Predation, competitive exclusion and diversity in the soft-sediment benthic communities of estuaries and lagoons. In: Levingston, R. J. (ed.) Ecological processes in coastal and marine systems. Plenum Press, New York, p. 233-264

Pielou, E. C. (1966). The measurement in different types of biological collections. J. theor. Biol. 13: 131-144

Rapport, D. I., Regier, H. A., Hutchinson, T C. (1985). Ecosystem behaviour under stress. Am. Nat. 125: 617-640

Rhoads, D. C., Young, D. K. (1970). The influence of depositfeeding organisms on sediment stability and community trophic structure. J. mar. Res. 28: 150-178

Rice, A. L., Billet, D. S. M., Fry, J., John, A. W. G., Lampitt, R. S., Mantoura, R. F. C., Morris, R. J. (1986). Seasonal deposition of phytodetritus to the deep-sea floor. Proc. R. Soc. Edinburgh 88B: 265-279

Rosenberg, R. (1976). Benthic faunal dynamics during succession following pollution abatement in a Swedish estuary. Oikos 27: 414-427

Rygg, B. (1986). Heavy-metal pollution and log-normal distribution of individuals among species in benthic communities. Mar. Pollut. Bull. 17: 31-36

Sanders, H. L. (1960). Benthic studies in Buzzards Bay. IrI. The 
structure of the soft bottom community. Limnol. Oceanogr. 5: $138-153$

Selye, H. (1973). The evolution of the stress concept. Am. Sci 61: $692-699$

Shannon, C. E., Weaver, W. W. (1963). The mathematical theory of communication. University Illinois Press, Urbana, p. $1-117$

Shilo, M. (1981). The toxic principles of Prymnesium parvum In: Carmichael, W. W. (ed.) The water environment. Algal toxins and health. Plenum Press, New York, p. 37-47

Siegel, S. (1956). Nonparametric statistics for the behavioral sciences. McGraw-Hill, New York, p. 1-312

Smayda, T. J. (1969). Some measurements on the sinking rate of fecal pellets. Limnol. Oceanogr. 14: 621-626

Smetacek, V. (1985). Role of sinking in diatom life-history cycles: ecological, evolutionary and geological significance. Mar. Biol, 84: 239-251

Smith, S. L., Lane, P. V. Z. (1988). Grazing of the spring diatom bloom in the New York Bight by the calanoid copepods Calanus finmarchicus, Metrida lucens and Centrophages typicus. Cont. Shelf Res. 8: 485-509

Sokal, R. R., Rohlf, F. J. (1981). Biometry: the principles and practice of statistics in biological research. W. H. Freeman, San Francisco, p. 1-776

Souprayen, J., Dauvin, J. C., Ibanez, F., Lopez-Jamar, E., O'Connor, B., Pearson, T. H. (1991). Long-term trends of subtidal macrobenthic communities: numerical analysis of four north-western European sites. In: Keegan, B. F. (ed.) Space and time series data analysis in coastal benthic ecology. The Coast 647 project in Commission of the Euro-

This article was submitted to the editor pean Communities (C.E.C.), Brussels, p. 265-438

Southgate, T. Wilson, K. Cross, T. F., Myers, A. A. (1984). Recolonization of a rocky shore in S.W. Ireland following a toxic bloom of the dinoflagellate, Gyrodinium aureoleum. J. mar. biol. Ass. U.K. 64: 485-492

Tangen, K. (1977). Blooms of Gyrodinium aureoleum (Dinophyceae) in north European waters accompanied by mortality in marine organisms. Sarsia 63: 123-133

Ter Braak, C. J. F. (1988). CANOCO-a FORTRAN program for canonical community ordination by (partial) (detrended) (canonical) correspondence analysis, principal components analysis and redundance analysis (version 3.10). TNO Inst. appl Comp. Sci., Stat. Dept., p. 1-95

Turner, J. T (1977). Sinking rates of fecal pellets from the marine copepod Pontella meadii. Mar. Biol. 40: 249-259

Underdal, B., Skulberg, O. M., Dahl, E., Aune, T. (1989). Disastrous bloom of Chrysochromulina polylepis (Prymenesiophyceae) in Norwegian coastal waters 1988. Mortality in marine biota. Ambio 18: 265-270

Warwick, R. M., Clarke, K. R., Suharsono (1990). A statistical analysis of coral community responses to the 1982-83 El Niño in the Thousand Islands, Indonesia. Coral Reefs 8 : $171-179$

Yasomoto, T., Underdal, B., Aune, T., Hormazabal, V., Skulberg, O. M., Oshima, Y. (1990). Screening for hemolytic and ichtyotoxic components of Chrysochromulina polylepis and Gyrodinium aureolum from Norwegian coastal waters. In: Granéli, E., Sundstrøm, B., Edler, E., Anderson, D. M. (eds.) Toxic marine phytoplankton. Elsevier, London, p. $436-440$

Manuscript first received: May 17, 1993

Revised version accepted: August 19, 1993 